\title{
New Protocols for the Assembly of the Tetracyclic Framework Associated with the Aromatic Erythrina Alkaloids
}

\author{
Pauline C. Stanislawski, Anthony C. Willis and Martin G. Banwell* \\ Research School of Chemistry, Institute of Advanced Studies, The Australian National University, \\ Canberra, ACT 0200, Australia \\ mgb@rsc.anu.edu.au
}

\section{Contents}

Page

General Experimental

Experimental Procedures and Product Characterization for Compounds:

$$
\text { 5-14, 4a-c, 17-20, and } 2
$$

Crystallographic Study on Compound 19

Figure 1: ORTEP Derived from Single-crystal X-ray Analysis of Compound 19

References

$300 \mathrm{MHz}{ }^{1} \mathrm{H}$ NMR Spectrum of Compound $\mathbf{4 c}$

$75 \mathrm{MHz}{ }^{13} \mathrm{C}$ NMR Spectrum of Compound 18

$800 \mathrm{MHz}{ }^{1} \mathrm{H}$ NMR Spectrum of Compound 2

$75 \mathrm{MHz}{ }^{13} \mathrm{C}$ NMR Spectrum of Compound 2 


\section{General Experimental Procedures}

Melting points were measured on a Stanford Research Systems Optimelt - Automated Melting Point System and are uncorrected. Proton $\left({ }^{1} \mathrm{H}\right)$ and carbon $\left({ }^{13} \mathrm{C}\right)$ NMR spectra were recorded on a Bruker 800, Varian Mercury 300 or Varian Inova 300 NMR spectrometer. Unless otherwise specified, spectra were acquired at $20{ }^{\circ} \mathrm{C}$ in deuterochloroform $\left(\mathrm{CDCl}_{3}\right)$ that had been filtered through basic alumina immediately prior to use. Chemical shifts are recorded as $\delta$ values in parts per million (ppm). Infrared spectra $\left(v_{\max }\right)$ were recorded on a Perkin-Elmer 1800 Series FTIR Spectrometer and samples were analyzed as $\mathrm{KBr}$ disks (for solids) or as thin films on $\mathrm{KBr}$ plates (for oils). Low resolution mass spectra were recorded on a Micromass-Waters LC-ZMD single quadrupole liquid chromatograph-MS or a VG Quattro II triple quadrupole MS instrument using electron impact techniques. High resolution mass spectra were recorded on an AUTOSPEC spectrometer. Dichloromethane (DCM) was distilled from calcium hydride and THF was distilled, under nitrogen, from sodium benzophenone ketyl. Where necessary, reactions were performed under a nitrogen atmosphere.

\section{6-Bromobenzo $[d][1,3]$ dioxole-5-carbaldehyde (5)}
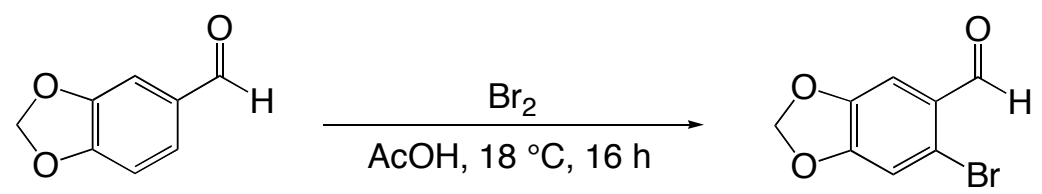

A magnetically stirred solution of piperonal $(20.0 \mathrm{~g}, 0.13 \mathrm{~mol})$ in glacial acetic acid (40 $\mathrm{mL})$ was treated with a solution of molecular bromine $(8.20 \mathrm{~mL}, 0.16 \mathrm{mmol})$ in glacial acetic acid $(25 \mathrm{~mL})$. The ensuing mixture was stirred at $18{ }^{\circ} \mathrm{C}$ for $16 \mathrm{~h}$ then poured into water $(1500 \mathrm{~mL})$. The precipitate so-formed was collected by filtration, washed thoroughly with $\mathrm{Na}_{2} \mathrm{~S}_{2} \mathrm{O}_{3}$ (50 mL of a saturated aqueous solution) then rapidly with icecold $\mathrm{Et}_{2} \mathrm{O}(1 \times 30 \mathrm{~mL})$ before being recrystallized $(\mathrm{MeOH})$ to give the title compound $\mathbf{5}^{1}$ $(17.1 \mathrm{~g}, 56 \%)$ as fine, white needles, mp $126-127^{\circ} \mathrm{C}$ (lit. ${ }^{1} \mathrm{mp} 129{ }^{\circ} \mathrm{C}$ ). 
${ }^{1}$ H NMR $\left(300 \mathrm{MHz}, \mathrm{CDCl}_{3}\right) \delta 10.18(\mathrm{~s}, 1 \mathrm{H}), 7.36(\mathrm{~s}, 1 \mathrm{H}), 7.06(\mathrm{~s}, 1 \mathrm{H}), 6.08(\mathrm{~s}, 2 \mathrm{H})$.

${ }^{13}$ C NMR (75 MHz, $\mathrm{CDCl}_{3}$ ) $\delta 190.4$ (CHO), 153.4 (C), 148.2 (C), 128.0 (C), 121.7 (C), $113.3(\mathrm{CH}), 108.1(\mathrm{CH}), 102.9\left(\mathrm{CH}_{2}\right)$.

IR $(\mathrm{KBr}) v_{\max } 3052,2920,2865,1674,1614,1596,1489,1412,1391,1347,1259,1112$, $1030,978,924,888,836 \mathrm{~cm}^{-1}$.

EIMS $(70 \mathrm{eV}) \mathrm{m} / z, 230$ and 228 (94 and 98\%, $\left.\mathbf{M}^{+*}\right), 229$ and 227 (100 and 97), 201 and 199 (25 and 32), 69 (69), 62 (60), 43 (52).

HRMS (EI) Found: $\mathrm{M}^{+\bullet}, 227.9419 . \mathrm{C}_{8} \mathrm{H}_{5}{ }^{79} \mathrm{BrO}_{3}$ requires $\mathrm{M}^{+\bullet}, 227.9422$.

Elemental Analysis Found: $\mathrm{C} 41.61 ; \mathrm{H} 2.28 . \mathrm{C}_{8} \mathrm{H}_{5} \mathrm{BrO}_{3}$ requires: $\mathrm{C} 41.95 ; \mathrm{H} 2.20 \%$.

\section{$E$ - and Z-5-Bromo-6-(2-methoxyvinyl)benzo[d][1,3]dioxole}

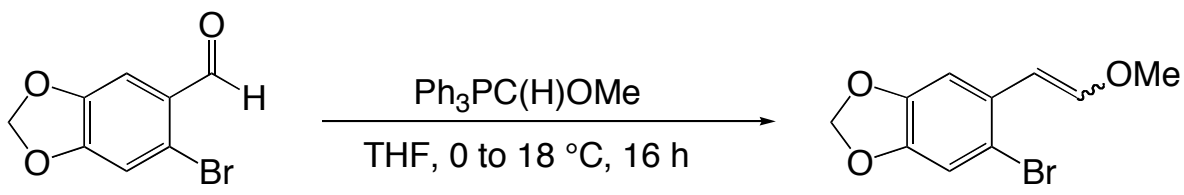

$t$-BuOK $(6.13 \mathrm{~g}, 54.6 \mathrm{mmol})$ was added in portions to an ice-cooled and magnetically stirred suspension of methoxymethyltriphenylphosphonium chloride (8.98 g, $26.2 \mathrm{mmol}$ ) in anhydrous THF (50 mL) maintained under an atmosphere of nitrogen. The resulting dark-red suspension was then stirred for $0.5 \mathrm{~h}$ at $c a .0{ }^{\circ} \mathrm{C}$. A solution of 6-bromopiperonal (5) $(5.00 \mathrm{~g}, 21.8 \mathrm{mmol})$ in THF (50 mL) was then added slowly and the ensuing mixture allowed to warm to $18{ }^{\circ} \mathrm{C}$ and stirred at this temperature for $16 \mathrm{~h}$. After this time $\mathrm{NH}_{4} \mathrm{Cl}$ (50 mL of a saturated aqueous solution) then water $(20 \mathrm{~mL})$ were added. The ensuing mixture was extracted with $\mathrm{Et}_{2} \mathrm{O}(3 \times 80 \mathrm{~mL})$ and the combined organic phases washed with brine $(1 \times 50 \mathrm{~mL})$ before being dried $\left(\mathrm{Na}_{2} \mathrm{SO}_{4}\right)$, filtered and concentrated under reduced pressure to give a light orange-colored and viscous oil. Subjection of this material to flash chromatography (silica, 4:96 v/v ethyl acetate/hexane elution) and concentration of the relevant fractions $\left(R_{\mathrm{f}} 0.4\right)$ under reduced pressure then gave a ca. 2:1 mixture of the $Z$ - and $E$-isomeric forms of the title compound $(5.21 \mathrm{~g}$, $93 \%$ ) as a clear, yellow oil. 
${ }^{1} \mathrm{H}$ NMR (300 MHz, CDCl ${ }_{3}$ ) Z-isomer: $\delta 7.62(\mathrm{~s}, 1 \mathrm{H}), 6.99$ (s, $\left.1 \mathrm{H}\right), 6.14(\mathrm{~d}, J 7.3 \mathrm{~Hz}$, 1H), 5.93 (s, 2H), 5.51 (d, J 7.3 Hz, 1H), 3.75 (s, 3H); $\boldsymbol{E}$-isomer: $\delta 6.98(\mathrm{~s}, 1 \mathrm{H}), 6.86(\mathrm{~d}$, $J 12.9 \mathrm{~Hz}, 1 \mathrm{H}), 6.81(\mathrm{~s}, 1 \mathrm{H}), 6.01(\mathrm{~d}, J 12.9 \mathrm{~Hz}, 1 \mathrm{H}), 5.93(\mathrm{~s}, 2 \mathrm{H}), 3.70(\mathrm{~s}, 3 \mathrm{H})$.

${ }^{13}$ C NMR (75 MHz, $\mathrm{CDCl}_{3}$ ) Z-isomer: $\delta 148.0(\mathrm{CH}), 147.0$ (C), 146.1 (C), 128.6 (C), $113.4(\mathrm{C}), 112.4(\mathrm{CH}), 109.7(\mathrm{CH}), 103.9(\mathrm{CH}), 101.5\left(\mathrm{CH}_{2}\right), 56.5\left(\mathrm{CH}_{3}\right) ; \boldsymbol{E}$-isomer: $\delta$ $149.5(\mathrm{CH}), 147.6(\mathrm{C}), 146.6(\mathrm{C}), 129.5(\mathrm{C}), 113.3(\mathrm{C}), 112.7(\mathrm{CH}), 105.2(\mathrm{CH}), 104.6$ $(\mathrm{CH}), 101.6\left(\mathrm{CH}_{2}\right), 60.7\left(\mathrm{CH}_{3}\right)$.

IR (thin film) $v_{\max } 3006,2935,2897,1647,1502,1476,1418,1324,1289,1231,1121$, 1090, 1039, 933, 869, 839, $758 \mathrm{~cm}^{-1}$.

EIMS (70 eV) m/z 258 and 256 (both 95\%, $\mathrm{M}^{+*}$ ), 215 (37), 213 (62), 211 (27), 162 (100). HRMS (EI) Found: $\mathrm{M}^{+*}, 257.9713$ and 255.9736. $\mathrm{C}_{10} \mathrm{H}_{9}{ }^{81} \mathrm{BrO}_{3}$ and $\mathrm{C}_{10} \mathrm{H}_{9}{ }^{79} \mathrm{BrO}_{3}$ require $\mathrm{M}^{+\bullet}, 257.9715$ and 255.9735 , respectively.

Elemental Analysis Found: $\mathrm{C} 46.84 ; \mathrm{H} 3.47 ; \mathrm{Br} 31.02 . \mathrm{C}_{10} \mathrm{H}_{9} \mathrm{BrO}_{3}$ requires: $\mathrm{C} 46.72 ; \mathrm{H}$ 3.53; $\mathrm{Br} 31.08 \%$.

\section{2-\{5-Bromobenzo $[d][1,3]$ dioxo-6-yl\}acetaldehyde}
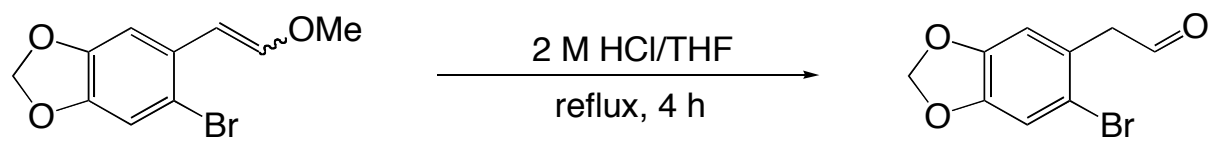

A magnetically stirred solution of a $c a$. 2:1 mixture of the $Z$ - and $E$-isomers of 5-bromo6-(2-methoxyvinyl)benzo[d][1,3]dioxole $(5.15 \mathrm{~g}, 20.0 \mathrm{mmol})$ and $\mathrm{HCl}(7 \mathrm{~mL}$ of a $2 \mathrm{M}$ aqueous solution) in THF $(45 \mathrm{~mL})$ was heated at reflux for $4 \mathrm{~h}$ then cooled to $18^{\circ} \mathrm{C}$ and extracted with $\mathrm{Et}_{2} \mathrm{O}(3 \times 150 \mathrm{~mL})$. The combined organic extracts were washed with water $(1 \times 50 \mathrm{~mL})$ and $\mathrm{NaHCO}_{3}(1 \times 50 \mathrm{~mL}$ of a saturated aqueous solution $)$, then dried $\left(\mathrm{Na}_{2} \mathrm{SO}_{4}\right)$, filtered and concentrated under reduced pressure to give the title compound $(4.86 \mathrm{~g}, 100 \%)$ as a pale-yellow and unstable oil that was used immediately in the next step of the reaction sequence. 
${ }^{1} \mathbf{H}$ NMR $\left(300 \mathrm{MHz}, \mathrm{CDCl}_{3}\right) \delta 9.71(\mathrm{t}, J 1.8 \mathrm{~Hz}, 1 \mathrm{H}), 7.05(\mathrm{~s}, 1 \mathrm{H}), 6.70(\mathrm{~s}, 1 \mathrm{H}), 5.99$ (broadened s, 2H), $3.76(\mathrm{~d}, J 1.8 \mathrm{~Hz}, 2 \mathrm{H})$.

\section{2-\{5-Bromobenzo[d][1,3]dioxol-6-yl\}ethanol (6)}
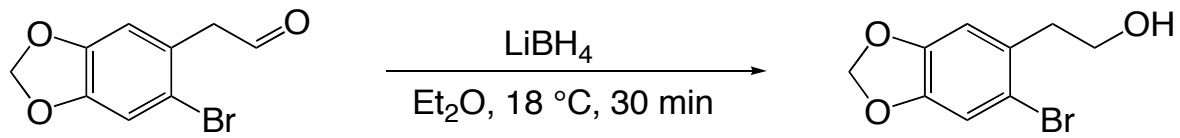

$\mathrm{LiBH}_{4}(479 \mathrm{mg}, 22.0 \mathrm{mmol}$ ) was added, in portions, to a magnetically stirred solution of 2-\{5-bromobenzo[ $d][1,3]$ dioxo-6-yl $\}$ acetaldehyde $(4.86 \mathrm{~g}, 20.0 \mathrm{mmol})$ in $\mathrm{Et}_{2} \mathrm{O}(60 \mathrm{~mL})$ maintained at $18{ }^{\circ} \mathrm{C}$ under an atmosphere of nitrogen. After $0.5 \mathrm{~h}$ the reaction mixture was treated with $\mathrm{NH}_{4} \mathrm{Cl}$ (15 mL of a saturated aqueous solution) then extracted with $\mathrm{Et}_{2} \mathrm{O}$ $(3 \times 80 \mathrm{~mL})$. The combined organic extracts were washed with brine $(1 \times 50 \mathrm{~mL})$ then dried $\left(\mathrm{Na}_{2} \mathrm{SO}_{4}\right)$, filtered and concentrated under reduced pressure to give a white solid. Subjection of this material to flash chromatography (silica, 2:8 $\rightarrow 3: 7 \mathrm{v} / \mathrm{v}$ ethyl acetate/hexane gradient elution) and concentration of the relevant fractions $\left(R_{\mathrm{f}} 0.2\right.$ in 1:4 $\mathrm{v} / \mathrm{v}$ ethyl acetate/hexane) gave the title alcohol $6^{2}(4.26 \mathrm{~g}, 87 \%)$ as a white, crystalline solid, mp 93-94 ${ }^{\circ} \mathrm{C}$.

${ }^{1} \mathbf{H}$ NMR $\left(300 \mathrm{MHz}, \mathrm{CDCl}_{3}\right) \delta 7.00(\mathrm{~s}, 1 \mathrm{H}), 6.76(\mathrm{~s}, 1 \mathrm{H}), 5.94(\mathrm{~s}, 2 \mathrm{H}), 3.81(\mathrm{t}, J 6.7 \mathrm{~Hz}$, 2H), $2.92(\mathrm{t}, J 6.7 \mathrm{~Hz}, 2 \mathrm{H}), 1.68(\mathrm{~s}, 1 \mathrm{H})$.

${ }^{13}$ C NMR (75 MHz, CDCl $)$ \& 147.5 (C), 147.2 (C), 130.9 (C), 114.8 (C), 112.9 (CH), $110.8(\mathrm{CH}), 101.8\left(\mathrm{CH}_{2}\right), 62.3\left(\mathrm{CH}_{2}\right), 39.3\left(\mathrm{CH}_{2}\right)$.

IR (KBr) $v_{\max } 3221,2937,2882,1505,1483,1235,1109,1049,930,864,835,680 \mathrm{~cm}^{-1}$.

EIMS $(70 \mathrm{eV}) \mathrm{m} / z 246$ and 244 (both 80\%, M+*), 216 and 214 (both 33), 215 and 213 (both 100), 164 (20), 157 (22), 135 (26), 78 (33), 75 (35).

HRMS (EI) Found: $\mathrm{M}^{+}, 245.9715$ and 243.9738. $\mathrm{C}_{9} \mathrm{H}_{9}{ }^{81} \mathrm{BrO}_{3}$ and $\mathrm{C}_{9} \mathrm{H}_{9}{ }^{79} \mathrm{BrO}_{3}$ require $\mathrm{M}^{+\bullet}, 245.9715$ and 243.9735, respectively.

Elemental Analysis Found: $\mathrm{C} 44.19 ; \mathrm{H} 3.66 ; \mathrm{Br} 32.35 . \mathrm{C}_{9} \mathrm{H}_{9} \mathrm{BrO}_{3}$ requires: $\mathrm{C} 44.11 ; \mathrm{H}$ $3.70 ; \mathrm{Br} 32.60 \%$. 


\section{(2-\{5-Bromobenzo[d][1,3]dioxol-6-yl\}ethoxy)(tert-butyl)diphenylsilane (7)}

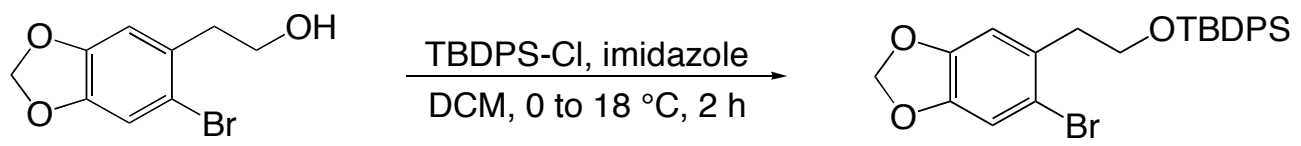

TBDPS-Cl (4.28 mL, $16.5 \mathrm{mmol})$ was added, dropwise, to an ice-cooled and magnetically stirred solution of alcohol 6 (3.36 g, $13.7 \mathrm{mmol})$ and imidazole $(2.05 \mathrm{~g}, 30.2$ $\mathrm{mmol})$ in dichloromethane $(60 \mathrm{~mL})$ maintained under an atmosphere of nitrogen. After $\sim 5$ min, the cooling bath was removed and the reaction mixture allowed to warm to $18{ }^{\circ} \mathrm{C}$. After $1.5-2 \mathrm{~h}$ at this temperature, the reaction mixture was diluted with dichloromethane $(60 \mathrm{~mL})$ then washed with water $(1 \times 60 \mathrm{~mL})$ and brine $(1 \times 60 \mathrm{~mL})$ before being dried $\left(\mathrm{Na}_{2} \mathrm{SO}_{4}\right)$, filtered and concentrated under reduced pressure to give a pale-yellow and opaque oil. Subjection of this material to flash chromatography (silica, $3: 97 \mathrm{v} / \mathrm{v}$ ethyl acetate/hexane) and concentration of the relevant fractions $\left(R_{\mathrm{f}} 0.4\right.$ in 5:95 v/v ethyl acetate/hexane) gave the title compound $7(6.57 \mathrm{~g}, 99 \%)$ as a viscous, colorless and opaque oil.

${ }^{1} \mathbf{H}$ NMR $\left(300 \mathrm{MHz}, \mathrm{CDCl}_{3}\right) \delta$ 7.69-7.63 (complex m, 4H), 7.48-7.36 (complex m, 6H), $6.99(\mathrm{~s}, 1 \mathrm{H}), 6.75(\mathrm{~s}, 1 \mathrm{H}), 5.94(\mathrm{~s}, 2 \mathrm{H}), 3.87(\mathrm{t}, J 6.8 \mathrm{~Hz}, 2 \mathrm{H}), 2.97(\mathrm{t}, J 6.8 \mathrm{~Hz}, 2 \mathrm{H}), 1.09$ $(\mathrm{s}, 9 \mathrm{H})$.

${ }^{13}$ C NMR (75 MHz, $\left.\mathrm{CDCl}_{3}\right) \delta 147.2$ (C), $147.0(\mathrm{C}), 135.7(\mathrm{CH}), 133.8(\mathrm{C}), 131.4(\mathrm{C})$, $129.7(\mathrm{CH}), 127.8(\mathrm{CH}), 114.7(\mathrm{C}), 112.6(\mathrm{CH}), 111.3(\mathrm{CH}), 101.6\left(\mathrm{CH}_{2}\right), 63.4\left(\mathrm{CH}_{2}\right)$, $39.3\left(\mathrm{CH}_{2}\right), 27.0\left(\mathrm{CH}_{3}\right), 19.3(\mathrm{C})$.

IR (thin film) $v_{\max } 3071,2931,2857,1502,1477,1427,1246,1229,1112,1045,937$, $860,824,738,702,614,505 \mathrm{~cm}^{-1}$.

EIMS $(70 \mathrm{eV}) \mathrm{m} / z, 484$ and 482 (both $<1 \%, \mathrm{M}^{+\bullet}$ ), 483 and 481 (both $c a$. 1), 428 and 426 (95 and 100), 427 and 425 (76 and 74), 347 (27), 346 (46), 269 (30), 268 (33), 263 and 261 (both 29), 229 and 227 (30 and 33), 213 (40), 199 (54), 183 (52), 181 (46), 148 (44), 135 (36), 105 (36), 91 (39).

HRMS (EI) Found: $\mathrm{M}^{+\bullet}, 482.0920 . \mathrm{C}_{25} \mathrm{H}_{27}{ }^{79} \mathrm{BrO}_{3}$ Si requires $\mathrm{M}^{+\bullet}, 482.0913$.

Elemental Analysis Found: C 62.13; $\mathrm{H}$ 5.48; $\mathrm{Br}$ 16.78. $\mathrm{C}_{25} \mathrm{H}_{27} \mathrm{BrO}_{3} \mathrm{Si}$ requires: $\mathrm{C} 62.11$; H 5.63; Br 16.53\%. 


\section{Compound 8}

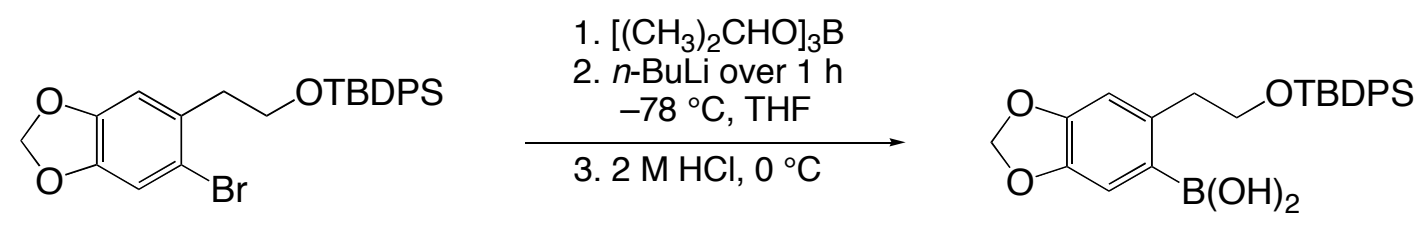

A magnetically stirred solution of aryl bromide $7(2.50 \mathrm{~g}, 5.17 \mathrm{mmol})$ and triisopropyl borate $(1.80 \mathrm{ml}, 7.80 \mathrm{mmol})$ in THF $(35 \mathrm{~mL})$ maintained under a nitrogen atmosphere was cooled to $-78{ }^{\circ} \mathrm{C}$ then treated, dropwise, with $n$-BuLi $(4.20 \mathrm{~mL}$ of a $1.6 \mathrm{M}$ solution in THF, $6.72 \mathrm{mmol}$ ) over a period of ca.1 h. The ensuing mixture was kept at $-78{ }^{\circ} \mathrm{C}$ for $1 \mathrm{~h}$, warmed to $0^{\circ} \mathrm{C}$ over $\mathrm{ca} .2 \mathrm{~h}$, then carefully acidified to $\mathrm{pH} 2-3$ with $\mathrm{HCl}(\mathrm{ca} .8 \mathrm{~mL}$ of a $2 \mathrm{M}$ aqueous solution), warmed to $18{ }^{\circ} \mathrm{C}$ and then stirred at this temperature for 5 to $10 \mathrm{~min}$ before being extracted into $\mathrm{Et}_{2} \mathrm{O}(3 \times 100 \mathrm{~mL})$. The combined organic extracts were washed with brine $(1 \times 80 \mathrm{~mL})$ then dried $\left(\mathrm{Na}_{2} \mathrm{SO}_{4}\right)$, filtered and concentrated under reduced pressure to give an opaque oil. Subjection of this material to flash chromatography (silica, 1:4 v/v ethyl acetate/hexane elution) and concentration of the relevant fractions $\left(R_{\mathrm{f}} 0.2\right)$ gave the title compound $\mathbf{8}(2.06 \mathrm{~g}, 89 \%)$ as a clear, colorless oil and as an admixture with various of the corresponding anhydrides. This material solidified upon cooling to $0{ }^{\circ} \mathrm{C}$ but decomposed on standing for prolonged periods at $18{ }^{\circ} \mathrm{C}$. Consequently this material was used immediately in the next step of the reaction sequence.

\section{Cyclopentenyl trifluoromethanesulfonate (9)}

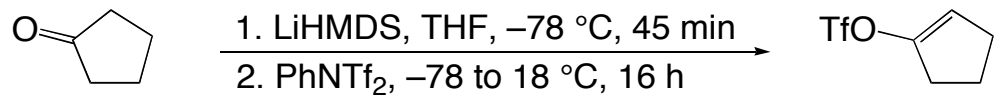

LiHMDS (14.0 $\mathrm{mL}$ of a $1.0 \mathrm{M}$ solution in THF, $14.0 \mathrm{mmol}$ ) was added, dropwise, to a magnetically stirred solution of cyclopentanone $(1.36 \mathrm{~mL}, 15.4 \mathrm{mmol})$ in THF $(25 \mathrm{~mL})$ maintained at $-78{ }^{\circ} \mathrm{C}$ under an atmosphere of nitrogen. After $c a .45 \mathrm{~min}$, a solution of 
$\operatorname{PhNTf}_{2}(5.00 \mathrm{~g}, 14.0 \mathrm{mmol})$ in THF (25 mL) was slowly added. The ensuing mixture was allowed to warm to $18{ }^{\circ} \mathrm{C}$ over a period of $3-4 \mathrm{~h}$, maintained at this temperature for $16 \mathrm{~h}$, treated with $\mathrm{NH}_{4} \mathrm{Cl}$ (30 mL of a saturated aqueous solution) then extracted with $\mathrm{Et}_{2} \mathrm{O}(3 \times$ $80 \mathrm{~mL})$. The combined organic extracts were washed with $\mathrm{Na}_{2} \mathrm{CO}_{3}(1 \times 50 \mathrm{~mL}$ of $2 \mathrm{M}$ aqueous solution) then dried $\left(\mathrm{Na}_{2} \mathrm{SO}_{4}\right)$, filtered and concentrated under reduced pressure to give an orange liquid. Subjection of this material to column chromatography (silica, pentane) and concentration of the relevant fractions $\left(R_{\mathrm{f}} 0.4\right)$ then gave cyclopentenyl trifluoromethanesulfonate ${ }^{3}(9)(2.02 \mathrm{~g}, 67 \%)$ as a clear, colorless and volatile liquid.

${ }^{1} \mathbf{H}$ NMR $\left(300 \mathrm{MHz}, \mathrm{C}_{6} \mathrm{D}_{6}\right) \delta 5.17$ (p, J 2.4 Hz, 1H), 2.16-2.06 (complex m, 2H), 1.831.74 (complex m, 2H), 1.45-1.33 (complex m, 2H).

${ }^{13}$ C NMR (75 MHz, C $\left.\mathrm{D}_{6}\right) \delta 149.8(\mathrm{C}), 119.3$ (q, J $\left.J_{19 \mathrm{~F}-13 \mathrm{C}} 322 \mathrm{~Hz}, \mathrm{C}\right), 117.9(\mathrm{CH}), 30.7$ $\left(\mathrm{CH}_{2}\right), 27.9\left(\mathrm{CH}_{2}\right), 20.8\left(\mathrm{CH}_{2}\right)$.

IR (thin film) $v_{\max } 2934,2864,1662,1423,1338,1250,1212,1143,1112,915,881,838$, $609 \mathrm{~cm}^{-1}$.

EIMS (70 eV) m/z, $216\left(\mathrm{M}^{+\bullet}, 14 \%\right), 98$ (26), 85 (30), 83 (23), 79 (20), 71 (36), 69 (55), 57 (100), 55 (68).

HRMS (EI) Found: $\mathrm{M}^{+\bullet}, 216.0072 . \mathrm{C}_{6} \mathrm{H}_{7} \mathrm{~F}_{3} \mathrm{O}_{3} \mathrm{~S}$ requires $\mathrm{M}^{+\bullet}, 216.0068$.

\section{Compound 10 and 2-\{5-Cyclopentenylbenzo[d][1,3]dioxol-6-yl $\}$ ethanol (11)}
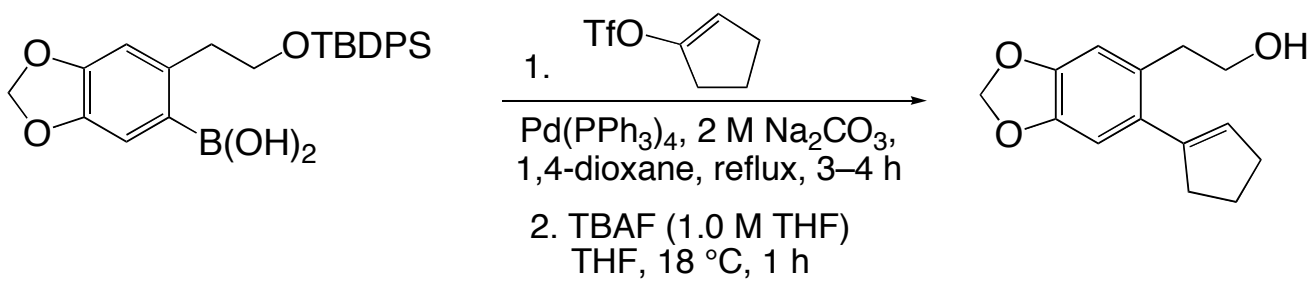

$\mathrm{THF}, 18^{\circ} \mathrm{C}, 1 \mathrm{~h}$

$\mathrm{Pd}\left(\mathrm{PPh}_{3}\right)_{4}(248 \mathrm{mg}, 215 \mu \mathrm{mol})$ was added to a degassed and magnetically stirred solution of boronic acid $8(2.06 \mathrm{~g}, 4.60 \mathrm{mmol})$ in 1,4-dioxane $(35 \mathrm{~mL})$ maintained under an atmosphere of nitrogen. $\mathrm{Na}_{2} \mathrm{CO}_{3}(2.76 \mathrm{~mL}$ of a degassed $2 \mathrm{M}$ aqueous solution, 5.52 mmol) was added to the reaction mixture followed by triflate $9(663 \mathrm{mg}, 3.07 \mathrm{mmol})$. The ensuing mixture was degassed (using the freeze-thaw process), magnetically stirred at 
reflux under a nitrogen atmosphere for $3-4 \mathrm{~h}$ then cooled to $18{ }^{\circ} \mathrm{C}$ and partitioned between $\mathrm{Et}_{2} \mathrm{O}(70 \mathrm{~mL})$ and water $(30 \mathrm{~mL})$. The separated aqueous phase was extracted into $\mathrm{Et}_{2} \mathrm{O}(3 \times 100 \mathrm{~mL})$ and the combined organic extracts washed with brine $(1 \times 60 \mathrm{~mL})$ before being dried $\left(\mathrm{Na}_{2} \mathrm{SO}_{4}\right)$, filtered and concentrated under reduced pressure to give a dark brown, viscous oil. Subjection of this material to flash chromatography (silica, 1:99 $\rightarrow$ 5:95 v/v ethyl acetate/hexane gradient elution) and concentration of the relevant fractions $\left(R_{\mathrm{f}} 0.5\right.$ in $5: 95 \mathrm{v} / \mathrm{v}$ ethyl acetate/hexane) under reduced pressure gave a mixture of the target compound $\mathbf{1 0}$ and material arising from the deborylation of substrate $\mathbf{8}$. A magnetically stirred solution of this mixture in THF $(35 \mathrm{~mL})$ was cooled to $c a .0{ }^{\circ} \mathrm{C}$, treated, dropwise, with TBAF (4.05 $\mathrm{mL}$ of a $1.0 \mathrm{M}$ solution in THF) then warmed to $18{ }^{\circ} \mathrm{C}$. After $1 \mathrm{~h}, \mathrm{NH}_{4} \mathrm{Cl}(20 \mathrm{~mL}$ of a saturated aqueous solution) was added to the reaction mixture which was then extracted into $\mathrm{Et}_{2} \mathrm{O}(3 \times 80 \mathrm{~mL})$. The combined organic extracts were washed with brine $(1 \times 70 \mathrm{~mL})$ then dried $\left(\mathrm{Na}_{2} \mathrm{SO}_{4}\right)$, filtered and concentration under reduced pressure to give a dark-orange oil. Subjection of this material to flash chromatography (silica, toluene then 1:99 $\rightarrow$ 2:99 v/v acetone/toluene gradient elution) and concentration of the relevant fractions $\left(R_{\mathrm{f}} 0.3\right.$ in 5:95 v/v acetone/toluene) gave the title compound 11 (346 mg, 49\% from 8) as a clear, ambercolored oil.

${ }^{1} \mathbf{H}$ NMR $\left(300 \mathrm{MHz}, \mathrm{CDCl}_{3}\right) \delta 6.72(\mathrm{~s}, 1 \mathrm{H}), 6.66(\mathrm{~s}, 1 \mathrm{H}), 5.92(\mathrm{~s}, 2 \mathrm{H}), 5.63(\mathrm{p}, J 2.3 \mathrm{~Hz}$, $1 \mathrm{H}), 3.77(\mathrm{t}, J 6.8 \mathrm{~Hz}, 2 \mathrm{H}), 2.85$ (t, $J 6.8 \mathrm{~Hz}, 2 \mathrm{H}), 2.62-2.53$ (complex m, 2H), 2.52-2.44 (complex m, 2H), 1.98 (p, J 7.7 Hz, 2H), 1.48 (broadened s, 1H).

${ }^{13}$ C NMR (75 MHz, C $6 \mathrm{D}_{6}$ ) $\delta 147.0$ (C), 146.4 (C), 143.5 (C), 135.3 (C), 129.9 (C), 129.2 $(\mathrm{CH}), 110.2(\mathrm{CH}), 109.0(\mathrm{CH}), 100.8\left(\mathrm{CH}_{2}\right), 63.9\left(\mathrm{CH}_{2}\right), 38.1\left(\mathrm{CH}_{2}\right), 36.8\left(\mathrm{CH}_{2}\right), 33.6$ $\left(\mathrm{CH}_{2}\right), 24.1\left(\mathrm{CH}_{2}\right)$.

IR (thin film) $v_{\max } 3340,2951,2889,1502,1483,1369,1218,1041,935,863 \mathrm{~cm}^{-1}$.

EIMS $(70 \mathrm{eV}) \mathrm{m} / z 233\left[(\mathrm{M}+\mathrm{H})^{+}, 34 \%\right], 232\left(\mathrm{M}^{+\bullet}, 100\right), 203$ (79), 201 (79), 189 (31), 173 (56), 171 (54), 160 (62), 143 (35), 128 (40), 115 (52).

HRMS (EI) Found: $\mathrm{M}^{+\bullet}, 232.1096 . \mathrm{C}_{14} \mathrm{H}_{16} \mathrm{O}_{3}$ requires $\mathrm{M}^{+\bullet}, 232.1099$. 


\section{2-\{5-Cyclopentenylbenzo[ $[d][1,3]$ dioxol-6-yl\}ethyl acetate (12)}

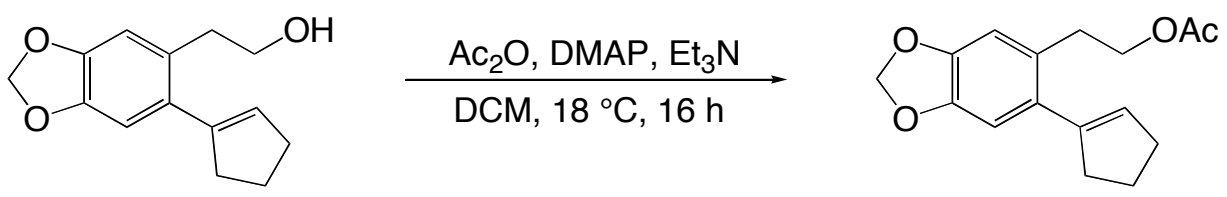

$\mathrm{Et}_{3} \mathrm{~N}(395 \mu \mathrm{L}, 2.83 \mathrm{mmol})$, DMAP (14 mg, $\left.113 \mu \mathrm{mol}\right)$ then $\mathrm{Ac}_{2} \mathrm{O}(267 \mu \mathrm{L}, 2.83 \mathrm{mmol})$ were added to a magnetically stirred solution of alcohol $11(263 \mathrm{mg}, 1.13 \mathrm{mmol})$ in anhydrous dichloromethane $(6 \mathrm{~mL})$ maintained at $18{ }^{\circ} \mathrm{C}$ under an atmosphere of nitrogen. After $16 \mathrm{~h} \mathrm{NaHCO}_{3}(5 \mathrm{~mL}$ of a saturated aqueous solution) was added and the ensuing mixture extracted with dichloromethane $(3 \times 30 \mathrm{~mL})$. The combined organic extracts were washed with brine $(1 \times 25 \mathrm{~mL})$ then dried $\left(\mathrm{Na}_{2} \mathrm{SO}_{4}\right)$, filtered and concentrated under reduced pressure to give a yellow oil. Subjection of this material to flash chromatography (silica, 5:95 $\rightarrow$ 7:93 v/v ethyl acetate/hexane gradient elution) then concentration of relevant fractions $\left(R_{\mathrm{f}} 0.2\right.$ in 5:95 v/v ethyl acetate/hexane) under reduced pressure gave the title compound $12(260 \mathrm{mg}, 84 \%)$ as a clear, light-yellow oil.

${ }^{1} \mathbf{H}$ NMR $\left(300 \mathrm{MHz}, \mathrm{CDCl}_{3}\right) \delta 6.71(\mathrm{~s}, 1 \mathrm{H}), 6.65$ (s, 1H), $5.91(\mathrm{~s}, 2 \mathrm{H}), 5.63$ (p, J $1.8 \mathrm{~Hz}$, 1H), 4.17 (t, J $7.3 \mathrm{~Hz}, 2 \mathrm{H}), 2.89$ (t, J $7.3 \mathrm{~Hz}, 2 \mathrm{H}), 2.62-2.44$ (complex m, 4H), 2.04 (s, $3 \mathrm{H}), 2.01(\mathrm{~m}, 2 \mathrm{H})$.

${ }^{13}$ C NMR (75 MHz, $\mathrm{CDCl}_{3}$ ) $\delta 171.1$ (CO), 146.5 (C), 146.1 (C), 142.8 (C), 132.7 (C), $129.5(\mathrm{CH}), 128.5(\mathrm{C}), 109.9(\mathrm{CH}), 108.8(\mathrm{CH}), 101.1\left(\mathrm{CH}_{2}\right), 65.3\left(\mathrm{CH}_{2}\right), 38.0\left(\mathrm{CH}_{2}\right)$, $33.6\left(\mathrm{CH}_{2}\right), 32.5\left(\mathrm{CH}_{2}\right), 23.9\left(\mathrm{CH}_{2}\right), 21.1\left(\mathrm{CH}_{3}\right)$.

IR (thin film) $v_{\max } 2953,2896,2846,1739,1503,1485,1384,1364,1236,1039,934$, $866 \mathrm{~cm}^{-1}$.

EIMS (70 eV) m/z, 275 [(M + H) $\left.{ }^{+}, 14 \%\right], 274\left(\mathrm{M}^{+\bullet}, 77\right), 215$ (22), 214 (99), 213 (34), 201

(14), 187 (22), 186 (96), 185 (100), 173 (26), 160 (21), 143 (15), 128 (30), 115 (33), 43 (52).

HRMS (EI) Found: $\mathrm{M}^{+\bullet}, 274.1200 . \mathrm{C}_{16} \mathrm{H}_{18} \mathrm{O}_{4}$ requires $\mathrm{M}^{+\bullet}, 274.1205$.

Elemental Analysis Found: $\mathrm{C} 70.34 ; \mathrm{H}$ 6.39. $\mathrm{C}_{16} \mathrm{H}_{18} \mathrm{O}_{4}$ requires: C 70.06; $\mathrm{H} 6.61 \%$. 
Compound 13 and 2-\{5-(6,6-Dichlorobicyclo[3.1.0]hexan-1-yl)benzo[ $d][1,3]$ dioxol-6yl\}ethanol
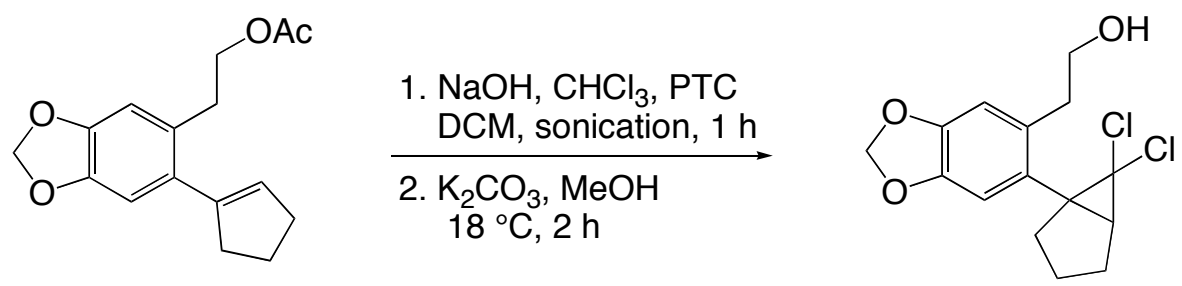

Powdered $\mathrm{NaOH}(199 \mathrm{mg}, 4.99 \mathrm{mmol})$, TEBAC (4 mg, $17 \mu \mathrm{mol})$ then $\mathrm{CHCl}_{3}(133 \mu \mathrm{L}$, $1.66 \mathrm{mmol})$ were added to a magnetically solution of acetate $\mathbf{1 2}(228 \mathrm{mg}, 831 \mu \mathrm{mol})$ in anhydrous dichloromethane $(580 \mu \mathrm{L})$ maintained under a nitrogen atmosphere at $18{ }^{\circ} \mathrm{C}$. The resulting mixture was sonicated for $1 \mathrm{~h}$ then allowed to cool to $18{ }^{\circ} \mathrm{C}$ and filtered through a pad of Celite ${ }^{\mathrm{TM}}$ that was washed well with dichloromethane. The combined filtrates were concentrated under reduced pressure to give a dark-brown oil containing compound 13. A solution of this material in $\mathrm{MeOH}(5 \mathrm{~mL})$ was treated with $\mathrm{K}_{2} \mathrm{CO}_{3}(126$ $\mathrm{mg}, 914 \mu \mathrm{mol})$ and the ensuing mixture stirred magnetically at $18{ }^{\circ} \mathrm{C}$ under an atmosphere of nitrogen for $2 \mathrm{~h}$. The solvent was then removed under reduced pressure and the residue partitioned between $\mathrm{Et}_{2} \mathrm{O}(30 \mathrm{~mL})$ and brine $(10 \mathrm{~mL})$. The separated aqueous phase was extracted with $\mathrm{Et}_{2} \mathrm{O}(2 \times 30 \mathrm{~mL})$ then the combined organic extracts were dried $\left(\mathrm{Na}_{2} \mathrm{SO}_{4}\right)$, filtered and concentrated under reduced pressure to give a brown oil. Subjection of this material to flash chromatography (silica, 1:4 v/v ethyl acetate/hexane elution) and concentration of the relevant fractions $\left(R_{\mathrm{f}} 0.2\right)$ under reduced pressure gave the title alcohol (254 mg, 97\% from 12) as a clear, pale-yellow oil.

${ }^{1} \mathrm{H}$ NMR $\left(300 \mathrm{MHz}, \mathrm{CDCl}_{3}\right) \delta 6.80(\mathrm{~s}, 1 \mathrm{H}), 6.42(\mathrm{~s}, 1 \mathrm{H}), 5.38(\mathrm{~d}, J 1.5 \mathrm{~Hz}, 1 \mathrm{H}), 5.34(\mathrm{~d}$, $J 1.5 \mathrm{~Hz}, 1 \mathrm{H}), 3.69(\mathrm{t}, J 6.9 \mathrm{~Hz}, 2 \mathrm{H}), 2.99$ (m, 1H), $2.84(\mathrm{~m}, 1 \mathrm{H}), 2.32(\mathrm{~m}, 1 \mathrm{H}), 1.94-1.72$ (complex m, 4H), 1.62-1.40 (complex m, 2H), 1.30 (broad s, 1H).

${ }^{13}$ C NMR (75 MHz, $\mathrm{CDCl}_{3}$ ) $\delta 147.5$ (C), 146.5 (C), 133.3 (C), 132.3 (C), 109.8 (CH), $108.7(\mathrm{CH}), 101.1\left(\mathrm{CH}_{2}\right), 72.9(\mathrm{C}), 63.4\left(\mathrm{CH}_{2}\right), 49.9(\mathrm{C}), 42.7(\mathrm{CH}), 37.1\left(\mathrm{CH}_{2}\right), 36.2$ $\left(\mathrm{CH}_{2}\right), 28.5\left(\mathrm{CH}_{2}\right), 26.2\left(\mathrm{CH}_{2}\right)$.

IR (thin film) $v_{\text {max }} 3351,2933,2883,1503,1486,1383,1239,1202,1042,936,868,826$ $\mathrm{cm}^{-1}$. 
EIMS $(70 \mathrm{eV}) \mathrm{m} / \mathrm{z}, 318,316$ and $314\left(\mathrm{M}^{+*}, 10,65\right.$ and 100\%), 287, 285 and $283(3,16$ and 24), 273, 271 and 269 (7, 41 and 64), 213 (65), 212 (50), 115 (78).

HRMS (EI) Found: $\mathrm{M}^{+*}, 316.0453$ and $314.0475 . \mathrm{C}_{15} \mathrm{H}_{16}{ }^{35} \mathrm{Cl}^{37} \mathrm{ClO}_{3}$ and $\mathrm{C}_{15} \mathrm{H}_{16}{ }^{35} \mathrm{Cl}_{2} \mathrm{O}_{3}$ require $\mathrm{M}^{+*}, 316.0447$ and 314.0477 , respectively.

\section{2-\{5-(6,6-Dichlorobicyclo[3.1.0]hexan-1-yl)benzo[ $d][1,3]$ dioxol-6-yl\}ethyl methanesulfonate}
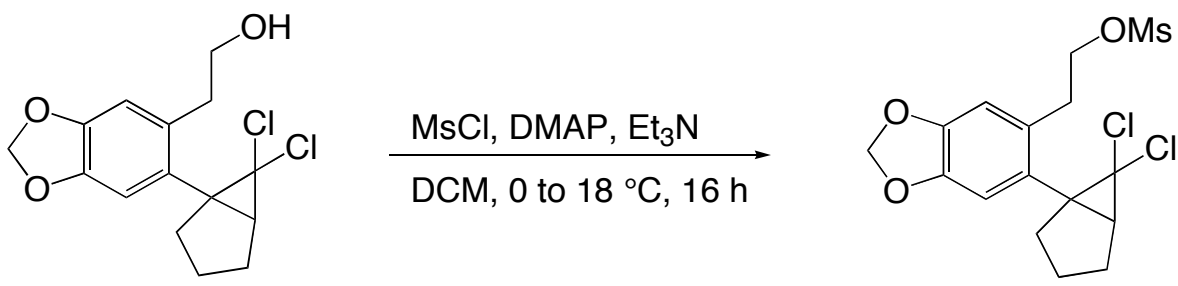

$\mathrm{Et}_{3} \mathrm{~N}(784 \mu \mathrm{L}, 5.62 \mathrm{mmol})$, DMAP $(27.0 \mathrm{mg}, 225 \mu \mathrm{mol})$ then $\mathrm{MsCl}(435 \mu \mathrm{L}, 5.62 \mathrm{mmol})$ were added to an ice-cooled and magnetically stirred solution of 2-\{5-(6,6dichlorobicyclo[3.1.0]hexan-1-yl)benzo[d][1,3]dioxol-6-yl\}ethanol (709 mg, $2.25 \mathrm{mmol}$ ) in dichloromethane $(20 \mathrm{~mL})$ maintained under an atmosphere of nitrogen. The ensuing mixture was warmed to $18{ }^{\circ} \mathrm{C}$ and stirred at this temperature for $16 \mathrm{~h}$. A solution of $\mathrm{NaHCO}_{3}(20 \mathrm{~mL}$ of a saturated aqueous solution) was then added and reaction mixture extracted with dichloromethane $(3 \times 50 \mathrm{~mL})$. The combined organic extracts were then dried $\left(\mathrm{Na}_{2} \mathrm{SO}_{4}\right)$, filtered and concentrated under reduced pressure to give an orange oil. Subjection of this material to flash chromatography (silica, 1:3 v/v ethyl acetate/hexane elution) and concentration of the relevant fractions $\left(R_{\mathrm{f}} 0.2\right)$ under reduced pressure gave the title mesylate ( $832 \mathrm{mg}, 94 \%$ ) as a viscous, cream-colored oil.

${ }^{1} \mathrm{H}$ NMR $\left(300 \mathrm{MHz}, \mathrm{CDCl}_{3}\right) \delta 6.78(\mathrm{~s}, 1 \mathrm{H}), 6.58(\mathrm{~s}, 1 \mathrm{H}), 5.94(\mathrm{~m}, 2 \mathrm{H}), 4.48(\mathrm{t}, J 7.2 \mathrm{~Hz}$, $2 \mathrm{H}$ ), 3.12 (m, 2H), 3.01 (s, 3H), 2.45-2.29 (complex m, 2H), 2.23-2.07 (complex m, 3H), 1.94-1.80 (complex m, 2H).

${ }^{13}$ C NMR $\left(75 \mathrm{MHz}, \mathrm{CDCl}_{3}\right) \delta$ 147.2, 146.7, 132.4, 129.8, 109.3, 108.7, 101.4, 72.1, 70.0, $49.4,42.9,37.7,36.9,32.2,28.5,26.2$. 
IR (thin film) $v_{\max } 2935,1504,1488,1355,1239,1174,1042,954,909,826,733,528$ $\mathrm{cm}^{-1}$.

EIMS $(70 \mathrm{eV}) \mathrm{m} / z$ 396, 394 and $392\left(\mathrm{M}^{+*}, 3,16\right.$ and 23$), 359$ and 357 (6 and 16), 358 and 356 (15 and 20), 271 and 269 (25 and 39), 263 and 261 (33 and 100), 226 (48), 225 (85), 213 (38), 195 (33).

HRMS (EI) Found: $\mathrm{M}^{+*}, 394.0225$ and 392.0258. $\mathrm{C}_{16} \mathrm{H}_{18}{ }^{35} \mathrm{Cl}^{37} \mathrm{ClO}_{5} \mathrm{~S}$ and $\mathrm{C}_{16} \mathrm{H}_{18}{ }^{35} \mathrm{Cl}_{2} \mathrm{O}_{5} \mathrm{~S}$ require $\mathrm{M}^{+*}, 394.0223$ and 392.0252 , respectively.

Elemental Analysis Found: $\mathrm{C} 48.62 ; \mathrm{H} 4.64 ; \mathrm{Cl} 18.35 . \mathrm{C}_{16} \mathrm{H}_{18} \mathrm{Cl}_{2} \mathrm{O}_{5} \mathrm{~S}$ requires: $\mathrm{C} 48.86$; $\mathrm{H} 4.61 ; \mathrm{Cl} 18.03 \%$.

\section{5-(2-Azidoethyl)-6-\{6,6-dichlorobicyclo[3.1.0]hexan-1-yl\}benzo[d][1,3]dioxole (14)}
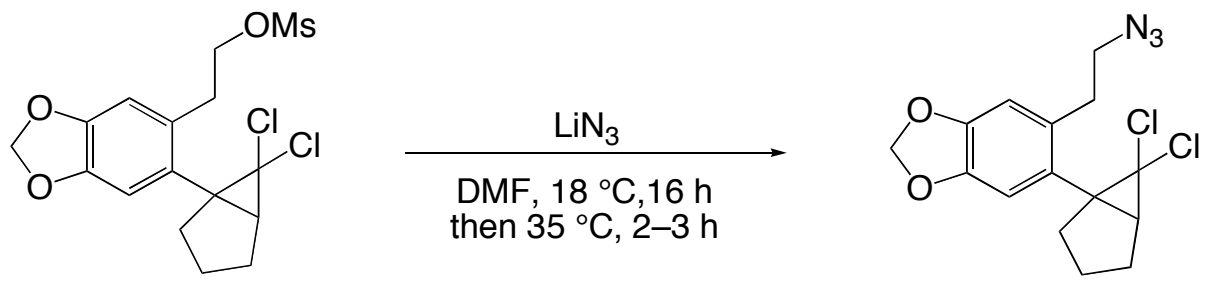

$\mathrm{LiN}_{3}$ (183 mg, $\left.3.75 \mathrm{mmol}\right)$ was added to a magnetically stirred solution of 2-\{5-(6,6dichlorobicyclo[3.1.0]hexan-1-yl)benzo[ $d][1,3]$ dioxol-6-yl\}ethyl methanesulfonate (491 $\mathrm{mg}, 1.25 \mathrm{mmol})$ in anhydrous DMF $(6 \mathrm{~mL})$ and the resulting mixture was stirred under an atmosphere of nitrogen at $18{ }^{\circ} \mathrm{C}$ for $16 \mathrm{~h}$, heated at $35^{\circ} \mathrm{C}$ for $2-3 \mathrm{~h}$ then allowed to cool to $18{ }^{\circ} \mathrm{C}$ and diluted with $\mathrm{Et}_{2} \mathrm{O}(50 \mathrm{~mL})$. The separated organic phase was washed with water $(3 \times 10 \mathrm{~mL})$ then dried $\left(\mathrm{Na}_{2} \mathrm{SO}_{4}\right)$, filtered and concentrated under reduced pressure to give a yellow oil. Subjection of this material to flash chromatography (silica, 5:95 v/v ethyl acetate/hexane elution) and concentration of the relevant fractions $\left(R_{\mathrm{f}} 0.3\right)$ under reduced pressure then gave the title compound $14(370 \mathrm{mg}, 87 \%)$ as a clear, pale-yellow and viscous oil.

${ }^{1} \mathbf{H}$ NMR $\left(300 \mathrm{MHz}, \mathrm{CDCl}_{3}\right) \delta 6.76(\mathrm{~s}, 1 \mathrm{H}), 6.58(\mathrm{~s}, 1 \mathrm{H}), 5.94(\mathrm{~m}, 2 \mathrm{H}), 3.57(\mathrm{~m}, 2 \mathrm{H})$, 2.97 (t, $J 7.5 \mathrm{~Hz}, 2 \mathrm{H}$ ), 2.47-2.24 (complex m, 2H), 2.23-2.08 (complex m, 3H), 1.981.75 (complex m, 2H). 
${ }^{13}$ C NMR $\left(75 \mathrm{MHz}, \mathrm{CDCl}_{3}\right) \delta 147.2,146.5,132.2,131.7,109.1,108.6,101.4,72.2,52.1$, $49.5,42.9,36.9,32.0,28.6,26.2$.

IR (thin film) $v_{\max } 2933,2098,1504,1486,1383,1350,1240,1202,1156,1116,1042$, $935,867,826 \mathrm{~cm}^{-1}$.

EIMS $(70 \mathrm{eV}) \mathrm{m} / z$ 343, 341 and $339\left(\mathrm{M}^{+\bullet}, 5,26\right.$ and 41\%), 314, 312 and 310 (2, 10 and 13), 278 and 276 (12 and 37), 249 and 247 (12 and 30), 228 (62), 212 (40), 189 (100), 153 (29), 115 (30).

HRMS (EI) Found: $\mathrm{M}^{+\bullet}, 339.0542 . \mathrm{C}_{15} \mathrm{H}_{15}{ }^{35} \mathrm{Cl}_{2} \mathrm{~N}_{3} \mathrm{O}_{2}$ requires $\mathrm{M}^{+\bullet}, 339.0541$.

Elemental Analysis Found: C 52.75; $\mathrm{H} 4.54 ; \mathrm{Cl} 20.83 ; \mathrm{N} 12.01 . \mathrm{C}_{15} \mathrm{H}_{15} \mathrm{Cl}_{2} \mathrm{~N}_{3} \mathrm{O}_{2}$ requires: C 52.96; H 4.44; Cl 20.84; N 12.35\%.

\section{Compound $4 \mathrm{a}$ and $O$-tert-Butyl $\quad N$-2-\{5-(6,6-dichlorobicyclo[3.1.10]hexan-1- yl)benzo[d][1,3]dioxol-6-yl\}ethyl carbamate (4b)}
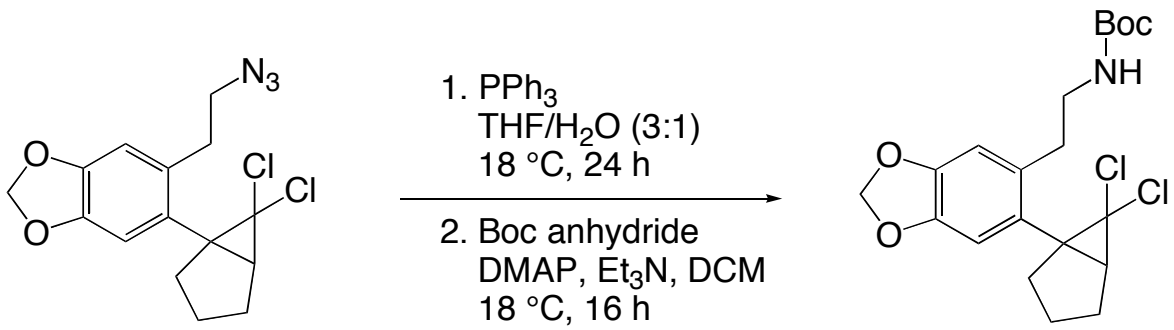

$\mathrm{PPh}_{3}(75 \mathrm{mg}, 286 \mu \mathrm{mol})$ was added to a magnetically stirred solution of azide $14(81 \mathrm{mg}$, $238 \mu \mathrm{mol})$ in $\mathrm{THF} /$ water $(1.4 \mathrm{~mL}$ of $10: 4 \mathrm{v} / \mathrm{v}$ mixture $)$ and the resulting mixture stirred at $18{ }^{\circ} \mathrm{C}$ for $16 \mathrm{~h}$. The solvent was removed under reduced pressure and the residue, containing the amine $4 a$, taken up in dichloromethane (3 mL). $\mathrm{Et}_{3} \mathrm{~N}(40 \mu \mathrm{L})$ and DMAP (3 mg, $24 \mu \mathrm{mol}$ ) were added, followed by Boc-anhydride (104 mg, $476 \mu \mathrm{mol}$ ). The resulting mixture was stirred at $18{ }^{\circ} \mathrm{C}$ for $48 \mathrm{~h}$ then partitioned between dichloromethane (30 $\mathrm{mL})$ and brine $(5 \mathrm{~mL})$. The separated aqueous phase was extracted into dichloromethane $(2 \times 30 \mathrm{~mL})$ and the combined organic extracts then dried $\left(\mathrm{Na}_{2} \mathrm{SO}_{4}\right)$, filtered and concentrated under reduced pressure to give a light-yellow oil. Subjection of this material to column chromatography (silica, 3:97 $\rightarrow$ 1:9 v/v ethyl acetate/hexane 
gradient elution) and concentration of the relevant fractions $\left(R_{\mathrm{f}} 0.4\right.$ in $1: 4 \mathrm{v} / \mathrm{v}$ ethyl acetate/hexane) under reduced pressure then gave the title compound $\mathbf{4 b}$ (45 $\mathrm{mg}, 45 \%$ over 2 steps) as a clear, yellow oil.

${ }^{1} \mathrm{H}$ NMR (300 MHz, $\mathrm{CDCl}_{3}$ ) $\delta$ (major rotamer) 6.77 (broad s, 1H), $6.56(\mathrm{~s}, 1 \mathrm{H}), 5.93(\mathrm{~m}$, 2H), 4.65 (broad s, 1H), 3.50-3.35 (complex m, 2H), 2.82 (m, 2H), 2.46-2.25 (complex m, 2H), 2.23-2.00 (complex m, 3H), 1.97-1.70 (complex m, 2H), 1.42 (s, 9H).

This material was used immediately in the next step of the reaction sequence.

\section{$O$-Allyl $\quad N$-2-\{5-(2-chloro-3-hydroxycyclohex-1-enyl)benzo[d][1,3]-dioxol-6-yl\}ethyl carbamate (4c)}
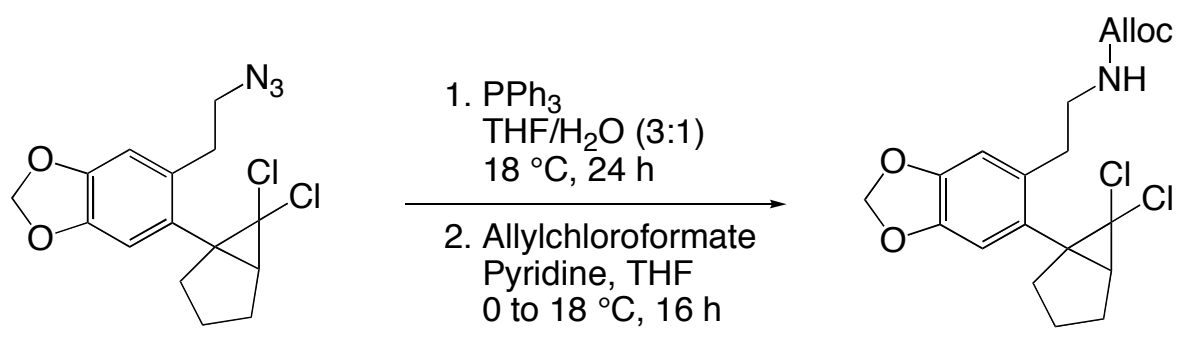

A magnetically stirred solution of amine 4a (prepared as described immediately above from $205 \mathrm{mg}$ of azide 14) in THF (4 mL) maintained under a nitrogen atmosphere was cooled to $0{ }^{\circ} \mathrm{C}$ then treated with pyridine $(73 \mu \mathrm{L}, 905 \mu \mathrm{mol})$ and allyl chloroformate (96 $\mu \mathrm{l}, 905 \mu \mathrm{mol})$. After $c a .10 \mathrm{~min}$. the reaction mixture was warmed to $18{ }^{\circ} \mathrm{C}$ and stirred at this temperature for $16 \mathrm{~h}$. The solvent was then removed under reduced pressure and the residue taken up in $\mathrm{Et}_{2} \mathrm{O}(50 \mathrm{~mL})$. The resulting solution was washed with water $(1 \times 5$ $\mathrm{mL})$ and then with brine $(1 \times 5 \mathrm{~mL})$ before being dried $\left(\mathrm{Na}_{2} \mathrm{SO}_{4}\right)$, filtered and concentrated under reduced pressure to give a yellow oil. Subjection of this material to flash chromatography (silica, 15:85 v/v ethyl acetate/hexane elution) and concentration of the relevant fractions $\left(R_{\mathrm{f}} 0.1\right)$ under reduced pressure afforded the title carbamate $4 \mathrm{c}$ (233 $\mathrm{mg}, 97 \%$ from 14) as a clear, viscous and colorless oil. 
${ }^{1} \mathrm{H}$ NMR $\left(300 \mathrm{MHz}, \mathrm{CDCl}_{3}\right) \delta$ (major rotamer) 6.76 (broad s, 1H), $6.56(\mathrm{~s}, 1 \mathrm{H}), 5.92(\mathrm{~m}$, 2H), 5.86 (partially obscured m, 1H), 5.29 (dd, $J 17.2$ and $1.4 \mathrm{~Hz}, 1 \mathrm{H}$ ), 5.20 (broadened d, $J 10.3 \mathrm{~Hz}, 1 \mathrm{H}$ ), 4.89 (broad s, 1H, NH), 4.57 (broad d, J $5.5 \mathrm{~Hz}, 2 \mathrm{H}$ ), 3.58-3.43 (complex m, 2H), 2.97-2.76 (complex m, 2H), 2.48-2.25 (complex m, 2H), 2.24-2.03 (complex m, 3H), 1.96-1.68 (complex m, 2H).

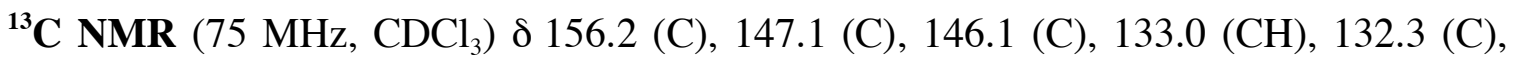
$132.0(\mathrm{C}), 117.6\left(\mathrm{CH}_{2}\right), 108.8(\mathrm{CH}), 108.4(\mathrm{CH}), 101.2\left(\mathrm{CH}_{2}\right), 72.2(\mathrm{C}), 65.5\left(\mathrm{CH}_{2}\right), 49.4$ $\left(\mathrm{CH}_{2}\right), 42.6(\mathrm{CH}), 41.7(\mathrm{C}), 36.7\left(\mathrm{CH}_{2}\right), 32.7\left(\mathrm{CH}_{2}\right), 28.4\left(\mathrm{CH}_{2}\right), 26.1\left(\mathrm{CH}_{2}\right)$.

IR (thin film) $v_{\max } 3338,2934,1712,1504,1486,1384,1239,1136,1041,992,935,827$, $776,733 \mathrm{~cm}^{-1}$.

EIMS $(70 \mathrm{eV}) \mathrm{m} / \mathrm{z}$ 401, 399 and $397\left(\mathrm{M}^{+*}, 1,6\right.$ and 10\%), 263 and 261 (24 and 74), 225 (57), 224 (50), 213 (58), 41 (100).

HRMS (EI) Found: $\mathrm{M}^{+\bullet}, 397.0848 . \mathrm{C}_{19} \mathrm{H}_{21}{ }^{35} \mathrm{Cl}_{2} \mathrm{NO}_{4}$ requires $\mathrm{M}^{+*}$, 397.0848.

\section{Compound 17}
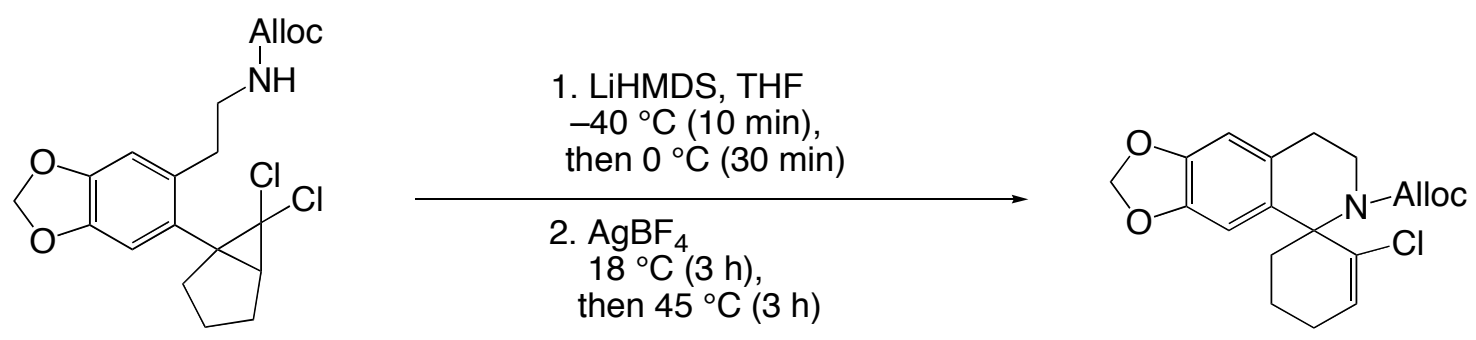

LiHMDS (95 $\mu \mathrm{L}$ of a $1.0 \mathrm{M}$ solution in THF, $95 \mu \mathrm{mol}$ ) was added to a magnetically stirred solution of gem-dichlorocyclopropane $4 \mathbf{c}(38 \mathrm{mg}, 95 \mu \mathrm{mol})$ in anhydrous THF (2 $\mathrm{mL}$ ) maintained at $-40^{\circ} \mathrm{C}$ under an atmosphere of argon. After $c a .10$ min. the reaction mixture was warmed to $0{ }^{\circ} \mathrm{C}$ and stirred at this temperature for a further $30 \mathrm{~min} . \mathrm{AgBF}_{4}$ ( $74 \mathrm{mg}, 382 \mu \mathrm{mol}$ ) was then added in one portion and after a further $10 \mathrm{~min}$. the reaction mixture was warmed to $18{ }^{\circ} \mathrm{C}$. After $3 \mathrm{~h}$ the reaction mixture was heated at $45^{\circ} \mathrm{C}$ for $3 \mathrm{~h}$. The cooled reaction mixture was then filtered through a pad of Celite ${ }^{\mathrm{TM}}$ and the filtrate concentrated under reduced pressure to give a brown oil. Subjection of this material to 
flash chromatography (silica, 1:9 v/v ethyl acetate/hexane elution) and concentration of the relevant fractions $\left(R_{\mathrm{f}} 0.2\right)$ under reduced pressure afforded the spirocyclic compound $17(25 \mathrm{mg}, 74 \%)$ as a clear, viscous and pale-yellow oil.

${ }^{1} \mathbf{H}$ NMR (300 MHz, $\left.\mathrm{CDCl}_{3}\right) \delta$ (major rotamer) $6.97(\mathrm{~s}, 1 \mathrm{H}), 6.65(\mathrm{~s}, 1 \mathrm{H}), 6.22$ (broadened s, 1H), 5.96 (broadened s, 2H), $5.33(\mathrm{dm}, J 17.3 \mathrm{~Hz}, 1 \mathrm{H}), 5.22(\mathrm{dm}, J 10.4$ $\mathrm{Hz}, 1 \mathrm{H}), 4.64$ (broadened d, J $5.4 \mathrm{~Hz}, 2 \mathrm{H}), 4.33$ (m, 1H), 3.13 (m, 1H), 2.95-2.77 (m, 2H), 2.68 (m, 1H), 2.50-2.10 (complex m, 2H), 1.60 (m, 4H).

${ }^{13}$ C NMR (75 MHz, $\left.\mathrm{CDCl}_{3}\right) \delta 154.0,146.5,146.0,133.3,131.3,130.2,128.8,118.0$, $117.2,108.5,108.4,101.2,65.9,64.9,43.9,37.4,30.3,25.6,18.7$.

IR (thin film) $v_{\max } 2932,1703,1503,1485,1390,1337,1249,1212,1039,933,859,769$ $\mathrm{cm}^{-1}$.

EIMS $(70 \mathrm{eV}) \mathrm{m} / z 363$ and $361\left(\mathrm{M}^{+*}, 12\right.$ and 32\%), 327 (15), $326(67), 322$ and 320 (12 and 34), 298 (40), 292 (40), 257 (100), 232 (22), 213 (63), 41 (88).

HRMS (EI) Found: $\mathrm{M}^{+\bullet}, 363.1051$ and 361.1083. $\mathrm{C}_{19} \mathrm{H}_{20}{ }^{37} \mathrm{ClNO}_{4}$ and $\mathrm{C}_{19} \mathrm{H}_{20}{ }^{35} \mathrm{ClNO}_{4}$ require $\mathrm{M}^{+\bullet}, 363.1051$ and 361.1081 , respectively.

\section{Compound 18}
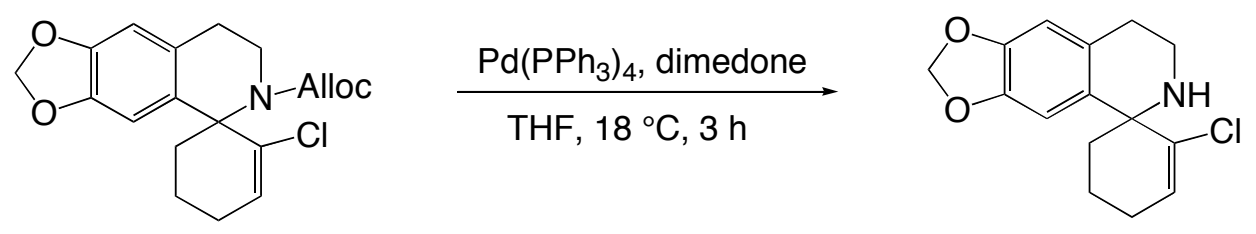

$\mathrm{Pd}\left(\mathrm{PPh}_{3}\right)_{4}(46 \mathrm{mg}, 40 \mu \mathrm{mol})$ and dimedone $(301 \mathrm{mg}, 2.14 \mathrm{mmol})$ were added to a magnetically stirred solution of carbamate 17 (97 mg, $268 \mu \mathrm{mol})$ in anhydrous THF (5 $\mathrm{mL}$ ) maintained at $18{ }^{\circ} \mathrm{C}$ under an atmosphere of nitrogen. After $3 \mathrm{~h}$ the solvent was removed under reduced pressure to give an orange oil. Subjection of this material to flash chromatography [silica, 9:1 v/v $\mathrm{CHCl}_{3} /\left(\mathrm{MeOH}\right.$ containing 5\% v/v $\left.880 \mathrm{NH}_{3}\right)$ ] and concentration of the relevant fractions $\left(R_{\mathrm{f}} 0.7\right)$ gave a mixture of the target amine and $\mathrm{Ph}_{3} \mathrm{P}(\mathrm{O})$. This mixture was subjected to further flash chromatography (silica, 1:1 v/v 
ethyl acetate/hexane) and concentration of the relevant fractions $\left(R_{\mathrm{f}} 0.3\right)$ under reduced pressure gave compound $18(70 \mathrm{mg}, 95 \%)$ as a clear, pale-orange oil.

${ }^{1}$ H NMR (300 MHz, $\left.\mathrm{CDCl}_{3}\right) \delta 6.60(\mathrm{~s}, 1 \mathrm{H}), 6.53(\mathrm{~s}, 1 \mathrm{H}), 6.11(\mathrm{t}, J 4.2 \mathrm{~Hz}, 1 \mathrm{H}), 5.90(\mathrm{~m}$, 2H), 3.20-3.00 (complex m, 2H), 2.79 (m, 1H), 2.55 (dt, $J 16.3$ and $3.3 \mathrm{~Hz}, 1 \mathrm{H}), 2.32-$ 2.16 (complex m, 4H), 1.82-1.62 (complex m, 2H) (signal due to NH not observed).

${ }^{13}$ C NMR (75 MHz, $\left.\mathrm{CDCl}_{3}\right) \delta 146.2,146.1,137.8,133.7,129.5,129.3,108.5,107.0$, $100.8,60.5,39.1,38.7,30.1,27.0,18.5$.

IR (thin film) $v_{\max } 2929,1712,1619,1595,1502,1483,1383,1233,1039,988,935,857$, $768,733 \mathrm{~cm}^{-1}$.

EIMS (70 eV) m/z 279 and $277\left(\mathrm{M}^{+\bullet}, 6\right.$ and 20\%), 251 and 249 (20 and 60), 250 and 248 (40 and 100), 242 (10), 221 and 219 (4 and 12), 213 (21), 202 (21).

HRMS (EI) Found: $\mathrm{M}^{+\bullet}, 277.0874 . \mathrm{C}_{15} \mathrm{H}_{16}{ }^{35} \mathrm{ClNO}_{2}$ requires $\mathrm{M}^{+\bullet}, 277.0870$.

\section{Compound 19}
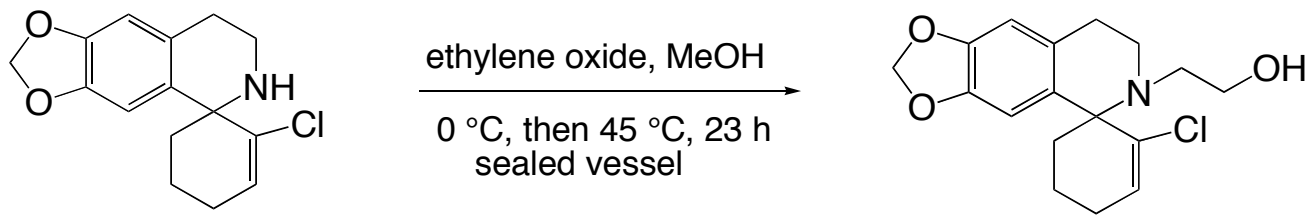

Ethylene oxide (ca. $2 \mathrm{~mL}$, ca. $40 \mathrm{mmol}$ ) was added to an ice-cooled solution of amine $\mathbf{1 8}$ (99 $\mathrm{mg}, 357 \mu \mathrm{mol})$ in anhydrous $\mathrm{MeOH}(1.0 \mathrm{~mL})$. The reaction vessel was sealed and the contents stirred magnetically at $45{ }^{\circ} \mathrm{C}$ for $16 \mathrm{~h}$ then cooled to $0{ }^{\circ} \mathrm{C}$ and additional ethylene oxide ( $c a .2 \mathrm{~mL}, c a .40 \mathrm{mmol}$ ) was added. The reaction vessel was resealed and the contents stirred magnetically at $45^{\circ} \mathrm{C}$ for $7 \mathrm{~h}$. The reaction mixture was again cooled to $18{ }^{\circ} \mathrm{C}$ and the solvent removed under reduced pressure to give an orange oil. Subjection of this material to flash chromatography (silica, 3:7 v/v ethyl acetate/hexane elution) and concentration of the relevant fractions $\left(R_{\mathrm{f}} 0.2\right)$ under reduced pressure afforded the title compound 19 (78 $\mathrm{mg}, 68 \%$ ) as white crystals, $\mathrm{mp} 113-115^{\circ} \mathrm{C}$.

${ }^{1} \mathbf{H}$ NMR $\left(300 \mathrm{MHz}, \mathrm{CDCl}_{3}\right) \delta 6.72(\mathrm{~s}, 1 \mathrm{H}), 6.54(\mathrm{~s}, 1 \mathrm{H}), 6.35(\mathrm{t}, J 4.4 \mathrm{~Hz}, 1 \mathrm{H}), 5.90$ (s, 2H), $3.73(\mathrm{td}, J 10.9$ and $3.2 \mathrm{~Hz}, 1 \mathrm{H}), 3.56(\mathrm{~m}, 1 \mathrm{H}), 3.15-2.80$ (complex m, 4H), 2.61 (m, 
1H), 2.49 (dm, J 12.5 Hz, 1H), 2.30-2.15 (complex m, 3H), 1.96-1.67 (complex m, 3H) (signal due to $\mathrm{OH}$ not observed).

${ }^{13}$ C NMR $\left(75 \mathrm{MHz}, \mathrm{CDCl}_{3}\right) \delta 146.3,145.8,136.3,133.7,132.5,128.0,108.4,107.2$, $100.9,65.0,58.2,51.6,41.2,32.9,29.8,26.3,19.5$.

IR (thin film) $v_{\text {max }} 3437,2934,2835,1502,1485,1384,1233,1124,1038,986,931,854$, $735 \mathrm{~cm}^{-1}$.

EIMS (70 eV) m/z 323 and $321\left(\mathrm{M}^{+*}, 9\right.$ and 25\%), 295 and 293 (10 and 34), 292 and 290 (36 and 100), 258 (58), 214 (56).

HRMS (EI) Found: $\mathrm{M}^{+*}, 323.1104$ and 321.1139. $\mathrm{C}_{17} \mathrm{H}_{20}{ }^{37} \mathrm{ClNO}_{3}$ and $\mathrm{C}_{17} \mathrm{H}_{20}{ }^{35} \mathrm{ClNO}_{3}$ require $\mathrm{M}^{+*}, 323.1102$ and 321.1132 , respectively.

Elemental Analysis Found: C 63.40; $\mathrm{H} 6.41 ; \mathrm{N}$ 4.14. $\mathrm{C}_{17} \mathrm{H}_{20} \mathrm{ClNO}_{3}$ requires: $\mathrm{C} 63.45 ; \mathrm{H}$ $6.26 ; \mathrm{N} 4.35 \%$.

\section{Compound 20}
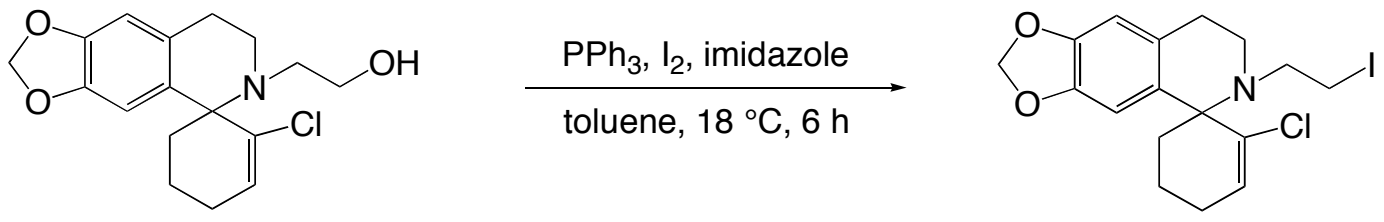

$\mathrm{PPh}_{3}(222 \mathrm{mg}, 845 \mu \mathrm{mol})$, imidazole (58 mg, $\left.845 \mu \mathrm{mol}\right)$ and iodine (161 mg, $\left.634 \mu \mathrm{mol}\right)$ were added to a magnetically stirred solution of alcohol $19(68 \mathrm{mg}, 211 \mu \mathrm{mol})$ in anhydrous toluene $(6 \mathrm{~mL})$. The reaction mixture was stirred at $18{ }^{\circ} \mathrm{C}$ under an atmosphere of nitrogen for $6 \mathrm{~h}$ then $\mathrm{Na}_{2} \mathrm{~S}_{2} \mathrm{O}_{3}(2 \mathrm{~mL}$ of a saturated aqueous solution) was added, stirring continued for $5 \mathrm{~min}$. and then it was extracted with ethyl acetate $(3 \times 40$ $\mathrm{mL})$. The combined organic extracts were dried $\left(\mathrm{Na}_{2} \mathrm{SO}_{4}\right)$, filtered and concentrated under reduced pressure to give a brown oil. Subjection of this material to flash chromatography (silica, 3:97 v/v ethyl acetate/hexane) and concentration of the relevant fractions $\left(R_{\mathrm{f}} 0.3\right.$, in 5:95 v/v ethyl acetate/hexane) under reduced pressure then gave the title iodide 20 (75 $\mathrm{mg}, 82 \%$ ) as a white solid, $\mathrm{mp} 136-148{ }^{\circ} \mathrm{C}$ (with decomposition from $136{ }^{\circ} \mathrm{C}$ ). 
${ }^{1} \mathbf{H}$ NMR $\left(300 \mathrm{MHz}, \mathrm{CDCl}_{3}\right) \delta 6.72(\mathrm{~s}, 1 \mathrm{H}), 6.55(\mathrm{~s}, 1 \mathrm{H}), 6.33$ (broadened t, $J 4.2 \mathrm{~Hz}$, 1H), 5.90 (s, 2H), 3.33-3.08 (complex m, 4H), 3.07-2.88 (complex m, 2H), 2.80-2.60 (complex m, 2H), 2.28 (m, 2H), 2.06-1.85 (complex m, 2H), 1.85-1.60 (complex m, $2 \mathrm{H})$.

${ }^{13}$ C NMR $\left(75 \mathrm{MHz}, \mathrm{CDCl}_{3}\right) \delta 146.3,145.7,136.4,133.3,132.0,127.9,108.7,107.3$, 100.9, 65.3, 54.6, 43.5, 33.7, 29.9, 26.3, 19.1, 5.0.

IR (thin film) $v_{\max } 2917,2835,1502,1483,1427,1384,1235,1162,1132,1098,1040$, $989,930,911,856,840,810,732 \mathrm{~cm}^{-1}$.

EIMS (70 eV) m/z 433 and $431\left(\mathrm{M}^{+*}, 4\right.$ and 11\%), 405 and 403 (5 and 16), 396 (45), 306 and 304 (32 and 100), 278 and 276 (32 and 94), 268 (24), 240 (55), 213 (48), 155 (35).

HRMS (EI) Found: $\mathrm{M}^{+*}, 433.0110$ and 431.0145. $\mathrm{C}_{17} \mathrm{H}_{19}{ }^{37} \mathrm{ClINO}_{2}$ and $\mathrm{C}_{17} \mathrm{H}_{19}{ }^{35} \mathrm{ClINO}_{2}$ require $\mathrm{M}^{+*}, 433.0120$ and 431.0149 , respectively.

\section{Compound 2}
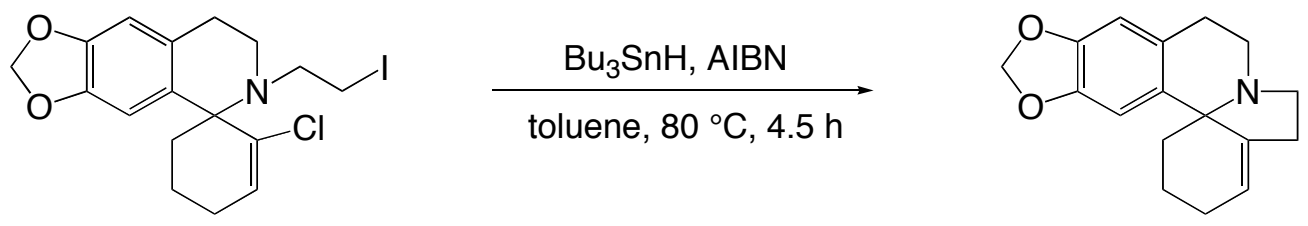

$\mathrm{Bu}_{3} \mathrm{SnH}(99 \mu \mathrm{L}, 367 \mu \mathrm{mol})$ was added over a period of $3 \mathrm{~h}$ to a magnetically stirred solution of AIBN ( $5 \mathrm{mg}, 33 \mu \mathrm{mol}$ - added in three equal aliquots over $2 \mathrm{~h}$ ) and iodide $\mathbf{2 0}$ (72 $\mathrm{mg}, 167 \mu \mathrm{mol})$ in anhydrous toluene $\left(17 \mathrm{~mL}\right.$ ) maintained at $80{ }^{\circ} \mathrm{C}$ under a nitrogen atmosphere. Once the addition of $\mathrm{Bu}_{3} \mathrm{SnH}$ was complete, the reaction mixture was maintained at $80{ }^{\circ} \mathrm{C}$ for a further 90 min then cooled to $18{ }^{\circ} \mathrm{C}$ and concentrated under reduced pressure. The residue was subjected to flash chromatography (silica, hexane $\rightarrow$ $1: 4 \mathrm{v} / \mathrm{v}$ dichloromethane/hexane $\rightarrow 1: 1 \mathrm{v} / \mathrm{v}$ dichloromethane/hexane $\rightarrow$ dichloromethane $\rightarrow$ 2.5:97.5 v/v methanol/dichloromethane $\rightarrow 5: 95 \mathrm{v} / \mathrm{v}$ methanol/dichloromethane $\rightarrow 1: 9$ $\mathrm{v} / \mathrm{v}$ methanol/dichloromethane $\rightarrow 1: 4 \quad \mathrm{v} / \mathrm{v}$ methanol/dichloromethane $\rightarrow 1: 1 \quad \mathrm{v} / \mathrm{v}$ methanol/dichloromethane $\rightarrow$ methanol) and concentration of the relevant fractions $\left(R_{\mathrm{f}}\right.$ 
0.2 in 5:95 v/v methanol/dichloromethane) under reduced pressure gave the title compound 2 (42 mg, 93\%) as a clear, pale-yellow and viscous oil.

${ }^{1}$ H NMR $\left(800 \mathrm{MHz}, \mathrm{CDCl}_{3}\right) \delta 6.66(\mathrm{~s}, 1 \mathrm{H}), 6.58(\mathrm{~s}, 1 \mathrm{H}), 5.89(\mathrm{~d}, J 1.6 \mathrm{~Hz}, 1 \mathrm{H}), 5.88(\mathrm{~d}$, $J 1.6 \mathrm{~Hz}, 1 \mathrm{H}), 5.75(\mathrm{~s}, 1 \mathrm{H}), 3.61(\mathrm{~m}, 1 \mathrm{H}), 3.18(\mathrm{~m}, 1 \mathrm{H}), 3.15(\mathrm{~m}, 1 \mathrm{H}), 2.98(\mathrm{~m}, 1 \mathrm{H})$, 2.76-2.67 (complex m, 2H), $2.52(\mathrm{~m}, 1 \mathrm{H}), 2.29(\mathrm{~m}, 1 \mathrm{H}), 2.22(\mathrm{~m}, 2 \mathrm{H}), 1.97(\mathrm{~m}, 1 \mathrm{H})$, $1.84(\mathrm{~m}, 1 \mathrm{H}), 1.74(\mathrm{~m}, 1 \mathrm{H}), 1.68(\mathrm{~m}, 1 \mathrm{H})$.

${ }^{13}$ C NMR (75 MHz, $\mathrm{CDCl}_{3}$ ) $\delta 146.7$ (C), 145.6 (C), 138.3 (C), 130.0 (C), 125.6 (C), $122.3(\mathrm{CH}), 108.8(\mathrm{CH}), 108.3(\mathrm{CH}), 100.9\left(\mathrm{CH}_{2}\right), 63.8(\mathrm{C}), 46.5\left(\mathrm{CH}_{2}\right), 41.2\left(\mathrm{CH}_{2}\right), 34.8$ $\left(\mathrm{CH}_{2}\right), 27.3\left(\mathrm{CH}_{2}\right), 24.2\left(\mathrm{CH}_{2}\right), 22.5\left(\mathrm{CH}_{2}\right), 17.3\left(\mathrm{CH}_{2}\right)$. IR (thin film) $v_{\max } 2932,1501,1481,1370,1234,1037,933 \mathrm{~cm}^{-1}$. EIMS (70 eV) m/z, $269\left(\mathrm{M}^{+\bullet}, 24 \%\right), 242$ (18), 241 (77), 240 (100).

HRMS (EI) Found: $\mathrm{M}^{+\bullet}, 269.1419 . \mathrm{C}_{17} \mathrm{H}_{19} \mathrm{NO}_{2}$ requires $\mathrm{M}^{+\bullet}, 269.1416$.

\section{Crystallographic Study on Compound 19}

Crystal data: $\mathrm{C}_{17} \mathrm{H}_{20} \mathrm{ClNO}_{3}, M=321.80, T=200(1) \mathrm{K}$, triclinic, space group $P \overline{\mathrm{I}}, Z=2, a=$ 7.4101(2), $b=10.2790(2), c=10.2887(3) \AA, \alpha=77.3182(16)^{\circ}, \beta=79.7927(16)^{\circ}, \gamma=81.7076$ $(16)^{\circ}, V=747.91(3) \AA^{3}, D_{x}=1.429 \mathrm{~g} \cdot \mathrm{cm}^{-3}, 3401$ unique data $\left(2 \theta_{\max }=55^{\circ}\right), 2802$ with $I>$ $3.0 \sigma(I) ; R=0.0302, R w=0.0381, S=1.0550$.

\section{Structure Determination}

Images were measured on a Nonius Kappa CCD diffractometer (MoK $\alpha$, graphite

monochromator, $\lambda=0.71073 \AA$ ) and data extracted using the DENZO package. ${ }^{4}$ Structure solution was by direct methods (SIR92). ${ }^{5}$ The structure of compound $\mathbf{1 6}$ was refined using the CRYSTALS program package. ${ }^{6}$ Atomic coordinates, bond lengths and angles, and displacement parameters have been deposited at the Cambridge Crystallographic Data Centre (CCDC 291532). These data can be obtained free-of-charge via www.ccdc.cam.ac.uk/data_request/cif, by emailing data_request@ccdc.cam.ac.uk, or by contacting The Cambridge Crystallographic Data Centre, 12, Union Road, Cambridge CB2 1EZ, UK; fax: +44 1223336033 . 


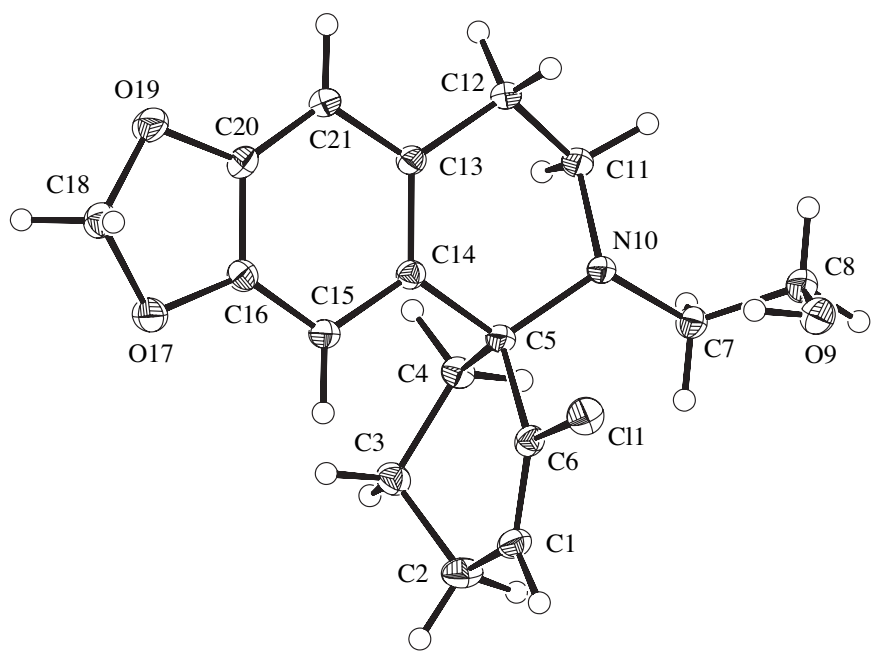

Figure 1. Molecular structure of $\mathrm{C}_{17} \mathrm{H}_{20} \mathrm{ClNO}_{3}$ (19) with labelling of non-hydrogen atoms. Anisotropic displacement ellipsoids show 30\% probability levels. Hydrogen atoms are drawn as circles with small radii.

\section{References}

1. P. C. Conrad, P. 1. Kwiatkowski and P. L. Fuchs, J. Org. Chem., 1987, 52, 586.

2. Y. Ogata, M. Ikeda, S. Nomoto, M. Okita, N. Shimomura, T. Kaneko, T. Yamanaka, I. Hishinuma and J. Nagakawa, Eur. Pat. Appl., 1988, 281098 (Chem. Abstr., 1989, 110, 95206).

3. J. Takagi, K. Takahashi, T. Ishiyama and N. Miyaura, J. Am. Chem. Soc., 2002, 124, 8001 and references cited therein.

4. DENZO-SMN. Z. Otwinowski and W. Minor, Processing of X-ray diffraction data collected in oscillation mode, Methods in Enzymology, Volume 276: Macromolecular Crystallography, Part A, eds. C. W. Carter Jr., and R. M. Sweets, Academic Press, pp. 307-326, 1997.

5. A. Altomare, M. Cascarano, C. Giacovazzo, A. Guagliardi, M. C. Burla, G. Polidori and M. Camalli, J. Appl. Crystallogr., 1994, 27, 435.

6. P. W. Betteridge, J. R. Carruthers, R. I. Cooper, K. Prout and D. J. Watkin, J. Appl. Crystallogr., 2003, 36, 1487. 
STANDARD 1H OBSERVE

$\exp 1$ stdih

DEC. \& VT

date May 252005 dfrq 300.067

solvent $\operatorname{CDCl3}$ an $\mathrm{H1}$

file /space/home/m dpwr 30

ercury/fids/23may0 dof

5 PS- 1.37 1

\begin{tabular}{ccc}
\multicolumn{2}{c}{ ACQUISITION } & $d \mathrm{~mm}$ \\
sfrq & 300.067 & $d \mathrm{mf}$
\end{tabular}

200

at 4.000 wtfile

at $\quad 36036$ proc

sw 4504.5 fn not used

$\mathrm{fb}$ not used

bs 16 werr

tpwr $\quad 58$ wexp

pw 6.0 wbs

d1 1.000 wht

tof 0

nt 16

ct

alock

FLAGS

$\begin{array}{ll}\text { il } & \mathbf{n} \\ \text { in } & \mathbf{n} \\ \text { dp } & \mathbf{y}\end{array}$

DISPLAY

187.3

3180.0

200

0
250

12.72

$\frac{2991.7}{2178.5}$

$\begin{array}{ll}1 \text { hh } & 10^{20} \\ \text { ins } & 2.000\end{array}$

m cdc ph
$300 \mathrm{MHz}{ }^{1} \mathrm{H}$ NMR Spectrum of Compound 4c (recorded in $\mathrm{CDCl}_{3}$ )<smiles>NCCc1cc2c(cc1C13CCCC1C3(Cl)Cl)OCO2</smiles> 
$\exp 5$ std13c

\begin{tabular}{|c|c|c|c|}
\hline \multicolumn{2}{|c|}{ SAMPLE } & \multicolumn{2}{|c|}{ DEC. \& VT } \\
\hline date & 22004 & dfrg & 299.945 \\
\hline \multicolumn{2}{|c|}{ solvent $\quad \operatorname{CDCl} 3$} & dn & H1 \\
\hline \multirow{2}{*}{\multicolumn{2}{|c|}{$\begin{array}{l}\text { file /disk1/fids/b- } \\
\text { anfids/es-3-44-056- }\end{array}$}} & dpwr & 42 \\
\hline & & dof & 0 \\
\hline \multicolumn{2}{|r|}{.fid } & $\mathrm{dm}$ & YYY \\
\hline \multicolumn{2}{|c|}{ ACQUISITION } & $d \mathrm{~mm}$ & 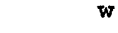 \\
\hline sfrq & 75.428 & $d m f$ & 6536 \\
\hline en & C13 & dseq & \\
\hline t & 0.910 & dres & 1.0 \\
\hline ap & 32768 & homo & $\mathrm{n}$ \\
\hline sw & 18001.8 & temp & 25.0 \\
\hline $\mathrm{Eb}$ & 10000 & \multicolumn{2}{|c|}{ PROCESSING } \\
\hline bs & 16 & 1b & 1.00 \\
\hline tpwx & 58 & wtfile & \\
\hline $\mathrm{pw}$ & 4.4 & proc & ft \\
\hline d1 & 1.000 & fn & 32768 \\
\hline$=0$ & 0 & math & $\mathbf{f}$ \\
\hline
\end{tabular}

nt 200000

ct 29600 werr

alock n wexp

gain not used wbs

FLAGS wnt

\begin{tabular}{|c|c|}
\hline iI & $n$ \\
\hline in & $n$ \\
\hline$d p$ & $y$ \\
\hline hs & $\mathrm{nn}$ \\
\hline
\end{tabular}

DISPLAY

SP $\quad 15.6$

vs 140

$\begin{array}{lr}\text { sc } & 0 \\ \text { wc } & 250\end{array}$

hzmm 60.75

is 500.00

rfl $\quad 7269.7$

rfp $\quad 5819.5$

ins 100.000

T I I I I T 100.000

180

160

140

120

100

80<smiles>ClC1=CCCCC12NCCc1cc3c(cc12)OCO3</smiles>

f 


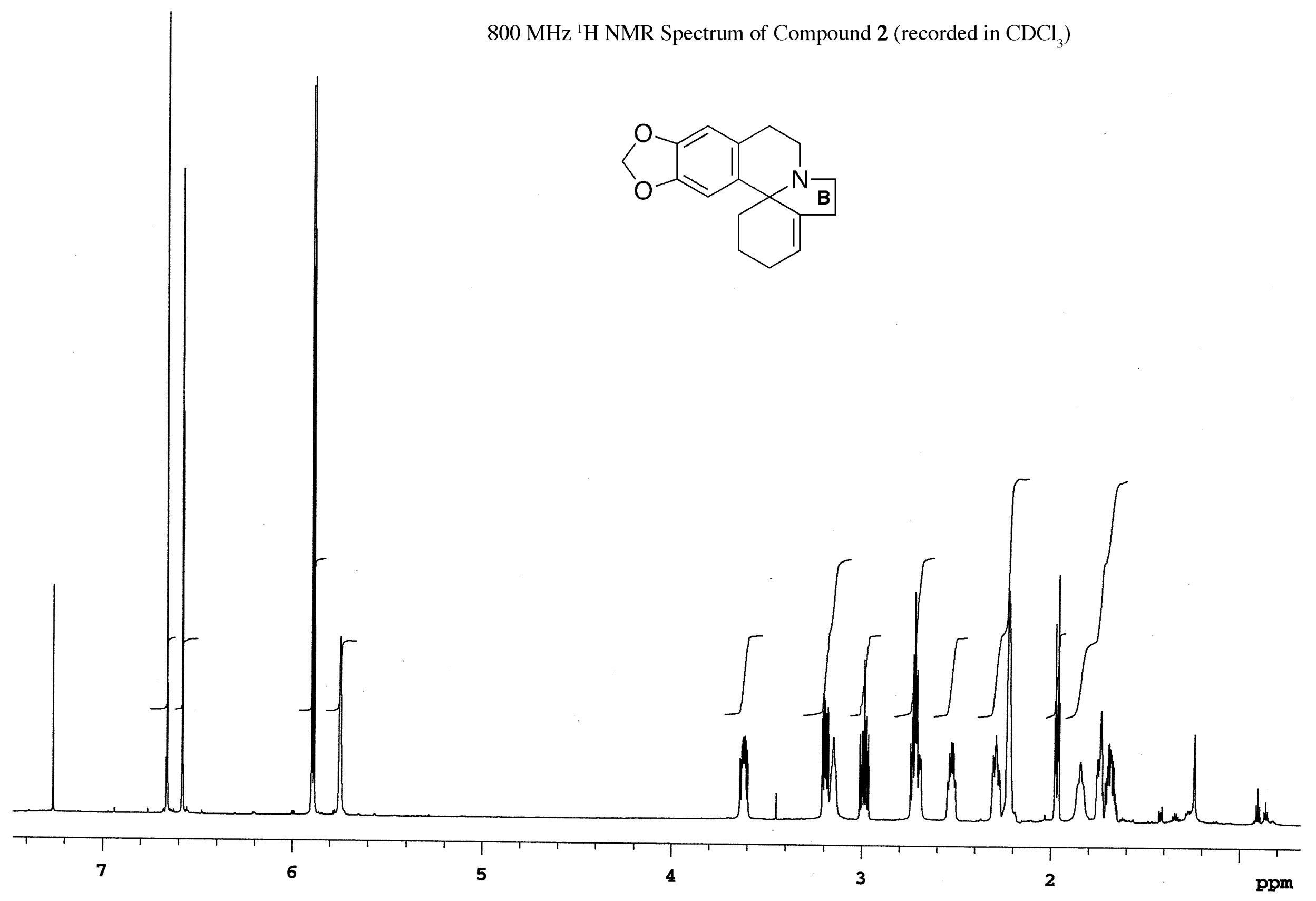




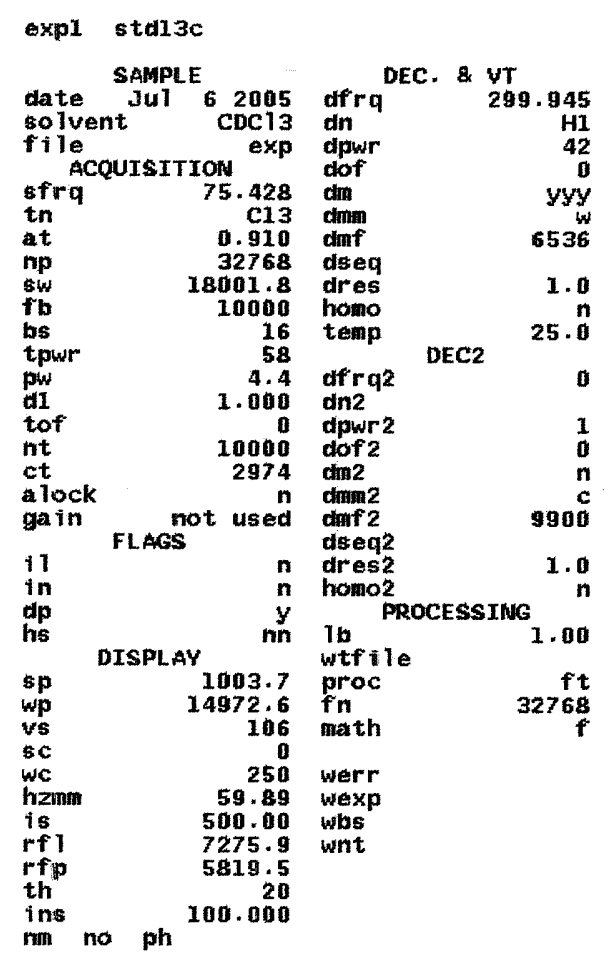

$75 \mathrm{MHz}{ }^{13} \mathrm{C}$ NMR Spectrum of Compound 2 (recorded in $\mathrm{CDCl}_{3}$ )

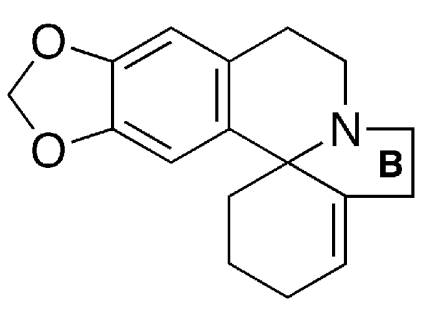

